\title{
The attempted merger between General Electric and Honeywell A case study of transatlantic conflict
}

\author{
Jeremy Grant \\ Graduate Institute of International Studies \\ Damien Neven \\ Graduate Institute of International Studies
}

\begin{abstract}
The thwarted merger of General Electric and Honeywell stands out as, so far, the only merger between US companies to be derailed solely by the European anti-trust authorities, while being cleared by the US Department of Justice (DoJ) and 11 other jurisdictions. In this paper, the authors examine the European Commission's decision, and the theories underlying it and compare the Commission's approach with that followed by the DoJ. They observe that the Commission and the DoJ had a different assessment of broadly similar facts, and attempt to understand the source of the divergence. The authors find that (i) the horizontal effects identified by the European Commission rely on a particular perspective of market definition which is debatable (and leaves some questions unanswered). (ii) The anti-competitive effects in the bundling and Archimedean leveraging theories are not sufficiently robust so that they could be resumed. Accordingly, their likelihood should be supported by strong evidence but the evidence presented by the Commission was far from compelling. (iii) The deal may have involved significant efficiencies that were overlooked. These observations raise the suspicion that the Commission's decision may have been affected by bureaucratic capture, such that civil servants did not follow the mandate that had been assigned to them. We find that the procedure enforced at the time was vulnerable to capture and that the Commission had an incorrect perception of the standard of review that the Court would apply to its decision in the context of an appeal. The accountability to which the Commission felt subject to was thus biased downwards and enlarged the scope for capture. In addition some (admittedly casual) evidence regarding the actual unfolding of the procedure, as well as subsequent reforms of process and procedure undertaken by the Commission, would support the view that significant problems arose in this area.
\end{abstract}

Acknowledgement: Financial support from the TMR program on « Competition Policy in international markets » is gratefully acknowledged. The authors would also 
like to thank all those participants in GE/Honeywell who generously gave of their time to discuss the case. (Acknowledgements to be approved). Thanks are also due to Sarah Nash at JP Morgan in New York. Helpful comments were also received from Dr. Thomas Kirchmaier at the LSE and Selman Ansari at Bates, Wells in London.

(C) The Authors.

All rights reserved. No part of this paper may be reproduced without the permission of the authors. 


\section{"In the macho world of merger regulation ..... authorities strive to win a tough reputation".}

\section{Introduction: Project Storm}

As General Electric's CEO Jack Welch strode onto the floor of the New York Stock Exchange on October $19^{\text {th }} 2000$, little did he know that he was about to become embroiled in a series of events that would lead to him bidding for Honeywell, a rival industrial conglomerate, and place him in the eye of a transatlantic storm over competition policy. ${ }^{2}$ The deal, codenamed Project Storm, would have been the largest industrial merger in history. Instead, it became infamous as the first, and so far only, merger between US companies to be derailed solely by the European anti-trust authorities, while being cleared by the US Department of Justice (DoJ) and 11 other jurisdictions.

This paper will critically examine the European Commission's decision, and the theories underlying it and compare the Commission's approach with that followed by the DoJ. We observe that the Commission and the DoJ had a different assessment of broadly similar facts, and attempt to understand the source of the divergence. In particular, we examine how process and procedure differed between the United States and the European Union, to determine what extent these factors influenced the outcomes of the regulatory processes on either side of the Atlantic.

While a significant amount has already been written on the case, systematic comparisons between the approaches followed by Commission and the DoJ have so far remained difficult because much of the DoJ' $s$ analysis is not in the public domain. In addition, little attention has been given so far to process and procedures. We attempt to gather systematic evidence on these issues; beyond an extensive survey of public sources currently available, we have extended our research through access to non-public sources including submissions to the regulators and other non- public research done at the time of the transaction. We have also conducted interviews with the regulators on both sides of the Atlantic and lawyers representing parties on both sides of the argument ${ }^{3}$.

Part I briefly reviews the Commission's decision, discusses possible sources of divergence and dismisses some of them as highly unlikely. Part II provides a critical review of the Commission's decision and highlights differences with the DoJ's analysis.

\footnotetext{
${ }^{1}$ Buck (2004).

${ }^{2}$ Welch and Byrne (2001).

${ }^{3}$ One of the authors also attended the GE and Honeywell appeal hearings at the European Court of First Instance in Luxembourg on May $25^{\text {th }}$ and $27^{\text {th }} 2004$. e
} 
Part III discusses the role that process and procedure have played in the emergence of divergent outcomes.

\section{Part 1: The European Commissions Case:}

The Commission's case was threefold. GE held a dominant position in the market for Large Jet Aircraft engines (between $43 \%$ and $65 \%$ depending on how market share was calculated) a situation where firms' conduct is subject to particular scrutiny under Article 82 of the Treaty of Rome. ${ }^{4}$ Meanwhile, Honeywell had a leading position in the avionics and non-avionics aerospace component markets. The European Union Merger Regulation enforced at the time prohibited mergers or acquisitions which "create or strengthen(s) a dominant position as a result of which effective competition would be significantly impeded in the common market". 5 According to the Commission, effective competition would be impeded mostly because of "conglomerate" effects. These may arise when the merging parties are active in different products markets ${ }^{6}$ and when the merger raises the scope for exclusionary practices.

The three main arguments in the case were as follows:

1) Bundling - The strength of the combined positions of the merging firms, the Commission feared, would allow GE to engage in exclusionary product bundling with the ultimate effect of foreclosing markets for single product line competitors (particularly Rolls Royce in aircraft engines and Rockwell Collins in aerospace components). Such foreclosure involves the deterrence of new entrants, the reduction of investment by existing competitors and possibly their exit.

\footnotetext{
${ }^{4}$ Art 82 ECT prohibits the abuse of a dominant position and not the dominant position by itself.

${ }^{5}$ The Merger Regulation has since been amended. The criterion for assessing mergers has been modified. Mergers which "would significantly impede effective competition, in the common market or in a substantial part of it, in particular as a result of the creation or strengthening of a dominant position" would now be held unlawful. The new formulation is meant to include horizontal mergers which have substantial unilateral effects despite the fact that merging partners do not reach the threshold of dominance. Given that the anti-competitive effects identified by the Commission in the GE/HW merger were primarily associated with conglomerate effects, and given that if anything, the criterion for horizontal effects have been strengthened, one can presume that, other things being equal, anti-competitive effects would also have been identified under the new merger regulation. The new merger regulation, however, emphasizes the role of efficiencies and the question arises whether efficiencies could have trumped anti-competitive effects under the new regime. This is further discussed below.

${ }^{6}$ The Commission first utilized the theory of "portfolio effects" in Guinness/Grand Metropolitan (1997). The merged entity was required to divest its rum distribution in Greece, although there was no horizontal overlap as only Grand Metropolitan was a rum distributor in the country. The reasoning was that the firm had too wide a portfolio of market leading brands, thus giving it extensive opportunities to increase market share via bundling and tying, and "will be able to realize economies of scope and scale in sales and marketing activities". In Coco Cola/Carlsberg (1998), the Commission required the divestiture of the $3^{\text {rd }}$ largest cola brand in Denmark and a bottling plant, because of fears of greater market power stemming from the combined companies drinks portfolio and resultant economies of scope and scale, although in this case there was clearly horizontal overlap. In both cases, the EC viewed enhancement of product portfolios post-merger as extending scope for exclusionary practices, which by their very nature would harm competitors.
} 
To back up its case, the EC put forward an economic model of bundling supplied by Rolls Royce and economic expert Professor Jay Pil Choi (Choi, 2001). ${ }^{7}$ The Commission claimed that the merged entity would have incentives to bundle its avionics (e.g. aircraft communication and navigation equipment) and non-avionics products (e.g. wheels, lights and landing gear) with engines, at a discount to single product purchases, which competitors could not match. In the short to medium term, this would marginalize competitors by depriving them of revenues which would mean they could not cover their fixed costs. In turn this would effect their spending destined for research and development on the next generation of products meaning they could not compete effectively with respect to future platforms .

The Commission presented evidence that Honeywell was already deploying bundling in what it designated as "multi-product" bids. The EC also received evidence from aerospace component competitors (in particular Rockwell Collins) that they had faced Honeywell component bundling, and were unable to compete. ${ }^{8}$ Therefore, if the deal were to proceed, they would have to withdraw from either the avionics or non-avionics businesses to concentrate their resources.

2) Archimedean Leveraging - GE would further increase its dominance by using the position of GE Capital Aviation Services (GECAS) in the market for leasing service. This was something GE had been doing since 1996 with its "GE only" policy of purchasing GE engines, where available, for the planes it leases to clients, and had two effects. Firstly, the Commission believed that substantial engine market share shifting to GE had been driven by this policy on multi-source platforms (i.e aircrafts for which several competing engines are certified, the choice of engine being made by the buyer). Secondly, the Commission believed that this policy could convince manufacturers to certify a GE engine on sole source platforms (where a single engine is certified). The Commission observed that in the market for Large Regional Jet, the 3 manufacturers choose GE as their single certified engine supplier, and GECAS subsequently ordered a large number of regional aircraft from each. The EC feared that "GE only" would be extended to Honeywell components, hence further transforming a leading market position into a dominant one, again leading to or re-enforcing market foreclosure. It went on to argue that this process would be aided by GE's financial strength demonstrated by its low market based cost of capital and triple AAA credit rating. These were all elements of "GE's toolkit for dominance" (Drauz, 2002).

This theory was controversial, not least because GE was being accused of market tipping with a market share of less than $10 \%$ in aircraft leasing. However, to bolster its case the Commission relied on an economic model of "Archimedean Leveraging" supplied to it

\footnotetext{
${ }^{7}$ Professor of Economics, Michigan State University.

${ }^{8}$ Source: Testimony given at Honeywell appeal hearing, Luxembourg May 25, 2004 - Rockwell's clients name was kept confidential.

${ }^{9}$ Interview with John DeQ. Briggs, Rockwell's American lawyer - Washington DC, February 2004.
} 
by United Technologies (UTC), a multi-product competitor of GE. ${ }^{10}$ This model purported to demonstrate how a firm with a limited presence (as a buyer) in a downstream, but not adjacent market, could affect competitive outcomes in upstream markets due to the embedded nature of the products concerned. GECAS role as launch customer for new aircraft models would further strengthen this effect as GECAS would "seed" airlines, particularly smaller and regional ones, with GE and Honeywell products. This might distort their later purchasing decisions in favor of General Electric products from air-framers and other leasing companies, as it lowers airlines costs to maintain "fleet commonality".

Overall, according to opponents of the deal, "the merger would have sandwiched airframers between their largest purchaser of aircraft, their largest supplier of avionics and other equipment, and a major source of finance for the building of new aircraft. At the same time, the combined firm would gain an advantage in the sale to airlines by bundling a broad range of products and seeding them with aircraft" (DeQ. Briggs and Rosenblatt, 2002) ${ }^{11}$.

3) Vertical and Horizontal Effects - The first two arguments related to "portfolio" and/or "conglomerate" effects (also known as range effects), areas of anti-trust regulation that remain contentious amo ngst economists and across jurisdictions. For its third line of argument, the EC returned to more traditional anti-trust areas: horizontal overlap in large regional and medium corporate jet engine markets and power systems. It also highlighted vertical issues related to Honeywell as the sole manufacturer and supplier of component engine starters to Rolls Royce. ${ }^{12}$

The Commission also claimed that the parties had not presented any efficiencies as a justification for the transaction. In principle, the analysis of efficiencies would allow the Commission to distinguish a merger that strengthens a company's market position through efficiencies that ultimately benefit consumer welfare, from one whose main purpose is to enable the combined entity to implement anti-competitive conduct including possibly predatory behavior, with the effect of marginalizing and ultimately driving its competitors from the market.

The Commission's reasoning behind the decision is extensively detailed in its final report which is 150 pages plus in length. By contrast, the US authorities cleared the merger, demanding only limited remedies detailed in a 2 page press release on May $2^{\text {nd }} 2001 .^{13}$

\footnotetext{
${ }^{10}$ Interestingly, Rolls Royce and UTC seemed to effectively coordinate their efforts. RR concentrated on bundling, while UTC based it arguments on the vertical integration of GECAS and share shifting. Clearly it was in their interests to not push the bundling argument in isolation as they had been the original purchasers of Honeywell, and were out-bid by GE.

${ }^{11}$ For an overview, see diagram in Appendix 1 presented by Rockwell Collins at appeal hearings of the European Court of First Instance in Luxembourg, May 2004.

${ }^{12}$ The parties did agree to a number of divestiture remedies in relation to some of these issues.

${ }^{13}$ The merged entity would be required to divest Honeywell's military helicopter engine business (approximately $\$ 200 \mathrm{~mm}$ in revenues) and open up the repair, maintenance and overhaul services for certain Honeywell engines and auxiliary power units, to further competition. (See http://www.usdoj.gov/atr/public/press_releases/2001/8140.htm). Subsequently, the DoJ did detail other
} 
Therefore, we are left with the question of how two regulatory authorities could come to such different outcomes. This is an important question as "such a wide divergence ... creates a lot of uncertainty - chaos - for business. This uncertainty will lead to behavior that we can well imagine would discourage firms from doing the sort of acquisitions that we would like them to be doing" (See Kogut, 2001 ${ }^{14}$ ).

In principle, one can identify the following possible sources of divergence. First, a divergence may occur because the authorities are subject to different legal standards. In particular, these standards may differ because they express different objectives or because the burden and the quantum of proofs do not coincide. For instance, one legal standard may give more importance to the prospect of prohibiting a pro-competitive merger than another, and may accordingly impose more stringent conditions on the evidence that is necessary to prohibit a merger. These objectives and rules governing evidence can be explicitly stated by the statutes or inferred from the relevant case law.

Second, the authorities may pursue different objectives from those that they have been assigned. The view of antitrust authorities as omniscient and benevolent agents seeking the public good has long been dismissed. These authorities are properly seen as a collection of agents pursuing their own objectives subject to an imperfect monitoring by the principal having assigned particular tasks to them. Being exposed to imperfect accountability, agents (civil servants) can take decisions which deviate from what the objectives that have been assigned to them would dictate, but achieve their own goals. This phenomenon is usually referred to as bureaucratic capture. For instance, a high profile prohibition may advance the career objectives of civil servants. In such an environment, interested parties may also try to influence the agents by offering prospects for further fulfillment of their objectives, which are made contingent on a particular course of action. Of course, the extent to which capture can arise is highly dependent upon the type of accountability that agents are subject to. In this respect, the procedures which govern the investigation as well as the prospects for appeal and the standard of review that will applied by the Courts will play an important role.

Third, different authorities may have a different judgment on a similar set of facts. Merger control involves a prospective exercise which is surrounded by much uncertainty and different agents may have genuinely different views.

Fourth, the concentration under review may have different consequences across jurisdictions. This may typically arise if the different jurisdictions belong to different geographically relevant markets, in which the conditions of competition may differ ${ }^{15}$.

aspects of its reasoning in a report submitted to the OECD on conglomerate mergers - ("Range Effects:

The United States Perspective" - http://www.usdoj.gov/atr/public/international/9550.pdf).

${ }^{14}$ Antitrust Fall, 2001, Roundtable Discussion, pg 9

${ }^{15}$ It may also arise if the jurisdictions belong to the same geographical market, but efficiencies differ across jurisdictions and the authorities pursue a total welfare standard (which takes into account the profit of the firms). 
At the outset, it would appear this last source of divergence is unlikely to have played a role in the case at hand, as both jurisdictions considered the relevant market as global. Some observers have also suggested that capture by wider political interests is at the source of divergence. In particular, it has been suggested that the US DoJ did not undertake a thorough investigation of the merger under pressure from GE and the incoming Bush Administration (see Kolasky, 2002 for a response). Meanwhile, the European Commission was accused of acting in the narrow protectionist interests of European companies and their member states (see DeQ. Briggs and Rosenblatt, 2001 for a response). ${ }^{16}$

It is not clear however that one should give much credence to these suggestions. First, regarding the claim that the DoJ did not undertake a proper investigation, it is worth noting that while the major analysis in the US was done in a period after a number of Clinton administration officials had departed the DoJ, ${ }^{17}$ and the Bush appointees had not arrived, a rigorous analysis was undertaken by the departments' career staff in the Office of Operations. The investigative team had in-depth knowledge of the aerospace industry, having previously examined the merger of Honeywell and AlliedSignal. The DoJ retained an external economist to assess the conglomerate effects doctrine with a track record suggesting that he was unlikely to dismiss such effects off hand. ${ }^{18}$

Second, regarding the claim that in challenging the merger, the European Commission was acting in the narrow protectionist interests of European companies and their home states, it is worth noticing that the major complainants in Europe included US firms such as United Technologies and Rockwell Collins. These, as we have already seen, provided significant elements of the Commissions case. Airbus, by contrast, appears not to have opposed the deal. In addition, it does not seem that the Commission has a track record suggesting that it favors EU firms in merger control, ${ }^{19}$ and we have not uncovered evidence suggesting that this case is different from others in this respect.

\footnotetext{
${ }^{16}$ For example, then US Treasury Secretary Paul O'Neill stated that the decision was "off the wall" and the Europeans were "meddling in things that one would think were outside their scope of attention" (Carney, 2001). Meanwhile, Senator Ernest Hollings, Chairman of the Senate Commerce Committee, sent a letter to the EC accusing them of "an apparent double standard by swiftly approving mergers involving European companies and holding up those of US groups. Its apparent EU disapproval gives credence to those who suspect that the EU is using its merger review process as a tool to protect and promote European industry at the expense of its US competitors." (DeQ. Briggs and Rosenblatt, 2001)

${ }^{17}$ For example, Joel Klein, Assistant Attorney General for Antitrust had left for a position at the Bertelsmann, while John Nannes the Acting Assistant Attorney General for Antitrust had to recuse himself. (DeQ. Briggs and Rosenblatt, 2001).

${ }^{18}$ Interestingly, the external expert was Professor Marius Schwartz who had previously served as the DoJ's Deputy Assistant Attorney General for Economics and Economics Director of Enforcement during the Clinton Administration. Schwartz had substantial research experience in vertical restraints and exclusionary practices including having published research with Dr Robert Reynolds, co-author of the Archimedean Leveraging theory. Source: Schwartz CV online at: www.georgetown.edu/faculty/schwarm2

${ }^{19}$ A number of econometric studies have analysed the outcome of merger control in the EU, in particular Lindsey and Williams (2003), Bergman et al. (2004) and Duso et al. (2003). These studies examine different samples and use different methods. None of them uncovers evidence of a bias against non EU firms.
} 
Differences in legal standards between the US and the EU have been much discussed (see for instance, Fox, 2002), both in terms of the substantive standard and in terms of the standard of proof that agencies are held to. Differences in substantive standards are probably such that the EU can be expected to prohibit mergers when the US may not, in particular because the EU legal framework may give more weight to the fate of competitors. But these differences are usually considered to be marginal. Similarly, differences in judgment will only affect outcomes in relatively marginal cases ${ }^{20}$. There is no clear indication either that agencies are held to different standards of proof, at least formally, as both are supposed in a way or another to show that anti-competitive effects would materialize "very probably",21. Hence, in order to identify the importance that capture (the third source of difference) may have played, a two pronged test can be developed. First, is it that the decision taken by the DoJ was "marginal"? If not, it will provide some (negative) evidence that capture may have played a role (competing hypotheses being inconsistent with this observation). Second, is it that the Commission's analysis rests on firm grounds? In particular, is it that the weight the Commission has attached to particular pieces of evidence appears well founded (relative to the DoJ). If not, it will suggest that capture has indeed played a role.

Whether the decision taken by the DoJ can be seen as marginal is difficult to assess in a systematic fashion; however, both the interviews with officials and lawyers involved as well as the DoJ's comments on the case (in particular in the context of the OECD) suggest that the DoJ had a lot of confidence in its decision. The second question, namely whether the Commission's analysis rests on firm grounds can be assessed through a detailed analysis of the Commission's published decision. This is the object of the main analytical section of this paper, which follows.

\section{Part 2: Re-Examining the Commission's Decision:}

\section{Overview of the Aerospace Market:}

\section{Jet Aircraft Engines:}

As we have seen, General Electric is a manufacturer of jet aircraft engines. Its main competitors are Rolls Royce of the UK and United Technologies (UTC), a US industrial conglomerate, through its subsidiary Pratt \& Whitney $(\mathrm{P} \& \mathrm{~W})$. The market is concentrated between these three independent players. Manufacturers sometimes compete to be the sole supplier of engines on each platform, in particular within the Regional and Corporate Jet category (see below). However, for most large commercial

\footnotetext{
${ }^{20}$ Assuming that both jurisdictions were exposed to a similar set of facts. This appears to be the case given that the DoJ and the Commission had extensive contacts and debates from the very beginning of the procedure (Source : interview with DoJ and Dg comp officials).

${ }^{21}$ See Kolasky (2002) and Versterdof (2004) on the standard of proof in merger cases. Of course, the significance of any particular standard of proof is largely determined by the standard of review that will applied by Courts in case of an appeal. As discussed below, there are good reasons to believe that the Commission was operation under an illusion with respect to standard of review that would apply in the event of an appeal.
} 
jets, the ultimate customer retains a choice of engines. ${ }^{22}$ Therefore, the competitive process in this area is two-stage. Firstly, the manufacturers compete to have their rival engines certified on a new plane. Secondly, they have to further compete to persuade the ultimate purchasers (airlines and leasers) to choose their engines over rivals, for the planes they are purchasing. ${ }^{23}$

Platforms can be broken down into 3 main categorizes based on aircraft size, and are used in order to define segments in the engine market (as larger planes require more powerful engines). The DoJ adopted a different approach based on the thrust of the engine itself. This issue will be further discussed below. For the time being, we follow the approach of the Commission. Each category is served by different aircraft manufacturers. (See Appendix 2 for a complete breakdown of each category by manufacturer, aircraft model, engine type and thrust).

1) Large Commercial Jets: In its decision, the Commission concentrated on the market for large commercial aircraft which is dominated by the duopoly of Airbus and Boeing. These can be sub-categorized into wide-bodied (twin aisle) and narrow-bodied (single aisle) aircraft, based on the number of passengers and mileage. The ultimate customers for these jets are airlines. Buyers from Airbus and Boeing are either the airlines or leasing companies.

2) Regional Jet Aircraft: In the next segment, regional jet aircraft, there were four manufacturers at the time of the decision, Bombardier, Fairchild Dornier, Embraer and British Aerospace. ${ }^{24}$ Regional jets can be sub-divided into large and small and are purchased by airlines, and in recent years, increasingly by leasing companies. The Commission found that there was a "clear growing focus of airlines on large regional jets .... demonstrated by the fact that such aircraft constituted 14\% of the European fleet in 1992 and 33\% in 1998" (pg 8).

3) Corporate Jet Aircraft: In this category there are a greater number of manufacturers including Gulfstream(General Dynamics), Raytheon, Dassault and Lear (Bombardier) amongst others. The ultimate customers are corporations and high net worth individuals. GE only manufactures one engine in this market, the CF34.

\footnotetext{
${ }^{22}$ A few platforms, most prominently the Boeing 737, sole source their engines (see Nalebuff, 2003 for a discussion of the rational behind such exclusive agreements).

${ }^{23}$ However, the 3 independent engine manufacturers have formed a number of joint ventures. Most prominent of these is CFMI, a joint venture between GE and SNECMA, a state owned French industrial firm (currently being privatized), which makes the CFM 56 engine. GE also has a joint venture with P\&W, the Engine Alliance. The other major joint venture is International Aero Engines (IAE), which was established by P\&W, Rolls Royce, MTU and Japanese Aero Engines. However, the Commission regards the 3 major firms as controlling all joint ventures they participate in.

${ }^{24}$ It should be noted that Fairchild Dornier subsequently went into bankruptcy and British Aerospace withdrew from this segment, ceasing to manufacture the Avro regional jet. Honeywell claimed that the Commission knew this at the time and should not have placed emphasis on this model in finding horizontal overlap in the engine market for large regional jets, as it was the only model for which Honeywell produced an engine. This would have been in line with the exclusion of the Fokker 70 and 100 LRJs which are no longer manufactured, and whose engines are solely supplied by Rolls Royce. Moreover, both GE and the DoJ defined the market based on the thrust power of the engines, which excluded the engines for the Avro, as their thrust was much lower than that of engines for other regional jets. See below for more details.
} 
The Commission found GE to be dominant in the market for engines for large commercial jets. It calculated market share based on current platforms and firm future orders. It specifically excluded "aircraft that remain in service, but are no longer manufactured" (pg 14). GE objected stating that the current installed base is not relevant in isolation, and would not explain how it overtook the leadership position of Pratt \& Whitney in the 1980's. P\&W had an 80\% market share in the 1960's. In fact, it had a 90\% market share as late as 1982 (Source: Back Associates Fleet Database, quoted in Emch (2003)). The turn around in the engine market was based on Boeing's launch of the 737 with GE/CFMI engines. The 737 went on to become the most successful aircraft in history, selling 4,000 of 13,000 large commercial aircraft over 20 years (Emch, 2003). Although, the first generation of 737s' were fitted with $\mathrm{P} \& \mathrm{~W}$ engines boosting its market share, the second and third generation's engines were sourced from GE/CFMI.

Therefore, it is clear that both GE and Rolls Royce emerged as competitive responses to P\&W's market dominance in the 1960's and 70's. However, GE has failed to achieve anything close to the same position $\mathrm{P} \& \mathrm{~W}$ once enjoyed. Moreover, GE/CFMI is a joint venture in which GE only receives half of the revenue stream, unlike $\mathrm{P} \& \mathrm{~W}$ which received $100 \%$ of all sales. This also suggests that even a $90 \%$ market share in an industry with high entry barriers can be challenged (that is, even when competitors would appear to be marginalized). Moreover, GE stated that the market was a bidding one subject to constant competition, and market shares can be transitory, as the P\&W case entailed. The latter argument was ignored by the Commission (the issue is further discussed below).

\section{Non-Avionics and Avionics Markets:}

Non-Avionics Products: These products include the basic components of an aircraft including wheels, brakes, landing gear, auxiliary power units, lighting and environmental controls.

Avionics: These products are employed to control the communication and navigation of the aircraft, as well as monitor external flying conditions. The market divides into two segments, large commercial aircraft (LCA) and regional corporate jets. Customers in the LCA market are the airframe manufacturers and also airlines and leasing companies. Avionics products are federated into a cockpit suite, which means that they can be chosen or changed by airline and leasing customers. This is the basis for a further segmentation:

1) Buyer Furnished Equipment (BFE): These products are chosen by the airlines. Standard avionics products tend to be buyer furnished. Such products are multi-sourced, and the final products are selected from 2 or 3 certified suppliers.

2) Supplier Furnished Equipment (SFE): Chosen by the airframe manufacturer. Non-avionics products, (except those like wheels and brakes) 
are supplier furnished. The competition between rival suppliers takes place at the time a new aircraft platform is being designed and developed.

However, for regional and corporate jets, avionics products are sold as part of an integrated cockpit. Therefore, the ultimate customers have no choice over the products.

The Commission defined Honeywell as having a leading position in the supply of aerospace components. In the avionics market, the EC calculates it holds a 50\% market share overall, followed by Rockwell Collins with $25 \%$, Thales with $18 \%$ and Smith Industries with $3 \%$.

In the non-avionics market, Honeywell competes against Hamilton Sundstrand (a subsidiary of United Technologies), BF Goodrich and SNECMA.

\section{Bidding Markets:}

The question arises whether the markets for aircraft engines and components can be characterized as "bidding market", where competitors are required to repeatedly bid against each other in order to win orders. In their investigation, the US authorities defined it as such. According to Shapiro and Patterson (2001) to determine this, the DoJ examined: (1) Whether multiple suppliers consistently entered the bidding contests to supply platforms and subsequently airlines? They found that this was indeed the case (Kolasky, 2002). (2) Did the customers determine that the competitors produced high quality alternative products, which gave them a real choice. Again, the DoJ answered this in the affirmative, after extensive surveys. Neither Boeing nor Airbus opposed the deal. ${ }^{25}$ (3) Are competing firms able to preserve their competitive advantages despite setbacks? The DoJ found that this was indeed the case, and that GE's competitors were thriving. In the DoJ's view, a high market share did not impact the ability of others to compete in future, as buyers did not regard it as a proxy for quality. If it was, then GE would never have been able to overtake Pratt \& Whitney in market share. The nature of competition is such that emphasis is on future competitions, not ones that have already been decided. (4) Is the bidding process vigorous, with multiple rounds of bidding that force down prices? The DoJ found that this was the case, and significant discounts were necessary to win orders. The European Commission confirmed this, but defined the discounts as evidence of the scope for anti-competitive practices on GE's part, rather than evidence of vigorous competition in the marketplace. ${ }^{26}$ (5) Where all competitors winning orders on a regular basis? As Kolasky (2002) states, "empirically, what we found when we examined the markets in which GE already competes, was that GE's engine rivals are both investing just as heavily as GE in developing their next generation of engines and have had no difficulty in raising capital to finance that effort." Overall, Platt Majoras $(2001)^{27}$ states

\footnotetext{
${ }^{25}$ However, a number of the airframer's customers did, although Lufthansa was the only airline to air its complaints openly.

${ }^{26}$ The Commission states, "These heavy discounting practices actually resulted in moving the break-even point of an engine project further away from the commercial launch of a platform".

${ }^{27}$ Deborah Platt Majoras, Deputy Assistant Attorney General for Anti-trust at the time of the decision, now Chairwomen of the Federal Trade Commission. Quote from speech made to the Anti-trust Section of the Georgia State Bar in 2001.
} 
that there was no evidence "supporting the EU finding that Rolls Royce and Pratt \& Whitney were no longer in a position to constrain GE's behaviour". These findings fundamentally undermine the market foreclosure argument put forward by the EC.

Therefore, in its approach, the Commission would appear to have ignored the dynamics of the market itself, and focused purely on market share, and a controversial definition at that (see above). ${ }^{28}$

\section{Unbundling Bundling:}

Having established GE's market dominance, the Commission then turned to the issue of bundling. There are two different types of bundling. Firstly, mixed bundling involves the sale of two products tied together as well as the sale of stand alone components. Mixed bundling can be incomplete if only one of the components, typically the tied good (in which the seller does not have a dominant position), is sold independently of the other. This is normally referred to as tying. The second type of bundling is pure bundling, where the 2 products are tied, and neither is available separately. (See Nalebuff, 2003 for more on these definitions). The type of bundling emphasized by the Commission was mixed bundling ${ }^{29}$.

Bundling: The Theory: In principle, bundling will allow sellers to undertake some profitable price discrimination. This arises because customers' valuation for the bundle may vary less than their valuation for individual items. As a result, the pricing of a bundle can escape, to some extent, the problem of any firm facing customers with different valuations (a demand curve) such that an increase in price will increase revenues from customers with high valuation, but lose the custom of those with low valuations. Bundling will increase profit, but it is not clear that welfare will fall and some customers will typically be better off.

\footnotetext{
${ }^{28}$ The Commission has defined bidders markets in previous cases such as Pirelli/BICC (2000) - there it defined it as where "tenders take place infrequently, while the value of each individual contract is usually very significant. Contracts are usually awarded to a single successful bidder (so-called "winner-takes-all" principle). Strong incentives therefore exist for all for all competitors to bid aggressively for each contract" (quoted from Shapiro and Patterson, 2001). The Commission has argued that in GE Honeywell it did not define the market as a bidders one because of structural features such as high entry barriers, commonality issues and the resource differentials of the players. The EC regards bidding markets to be more important to cases of collective dominance, than simple dominance. (Source: Interviews with the Merger Task Force Team members - Brussels).

${ }^{29}$ The Commission has found tying illegal where a firm holds a dominant position in relation to one of the products. See Hilti AG vs. Comm'n, Case C-53/92P, 1994 E.C.R I-667 (CJ), which relates to a German manufacturer of nail guns who attempted to exclude independent producers of nails for it products via tying the sale of its guns to its nails. The Commission has also found (complete) mixed bundling illegal when undertaken by firms who occupy dominant market positions. For example, Hoffman-La Roche v. Comm'n, Case 85/76, 1979 E.C.R. 461 (CJ) and Michelin NV v. Comm'n, Case 322/81, 1983 E.C.R. 2461 (CJ). In the latter case, the European Court of Justice declared that "no discount should be granted (by a dominant firm) unless linked to a genuine cost reduction in the manufacturers costs". Mixed bundling was a key element of the EC's case, particularly in the Statement of Objections (May, 2001). The EC placed some emphasis on pure bundling as theoretical future behavior by the merged parties in relation to new generations of aircraft.
} 
When bundling involves complements, a second effect comes into play. Complementary products are such that a fall in the price of one product will increase the demand for both; for instance, a decrease in the price of an engine will make planes more affordable and will thus increase demand for avionics as well as engines. When different firms sell the different components, they will not take this into account. For instance, a seller of engines will set its price considering only the effect that a change in price will have on the sale of engines. When complements are sold by the same firm, the matter is different. When pricing engines, the firm will also consider the effect that a fall in price will have on demand for avionics, besides engines. As a result, prices will be lower ${ }^{30}$. This is the so called Cournot effect; profits will increase but, since prices fall, consumers will also be better off ${ }^{31}$ Note that in those circumstances, pricing can be seen as more "efficient". 32

The Cournot effect is strongest with firms implement pure bundling and faces no competition. In the presence of competitors and mixed bundling matters are different. In the presence of competition, it is not clear that bundling will be profitable: lower prices for the bundle may trigger a response from competitors such that bundling is not attractive. Mixed bundling in the presence of competition may or may not be attractive depending on particular features of demand and in particular on the extent to which the decrease in the price of the bundle enlarges aggregate demand (as opposed to shifting market share). However, bundling will also typically be more profitable when it involves a large number of components. This arises because of a Counot effect in "reverse" ; in lowering its price to lure away consumer of the bundle, the manufacturer of any given component will produce a large external benefit to manufacturers of other components. Indeed, as he switches away from the bundle, each consumer will have to choose a variety of components. This external effects will not be internalized and lead to higher prices (a weaker response) by competitors. Overall, if the profitability of bundling is somewhat uncertain, bundling will generally tend to lower the demand faced by competitors in each market. They can expect to suffer both because of lower prices, and because bundling allows for some price discrimination (which effectively enhances the bundling firms' ability to extract profits from buyers) ${ }^{33}$. The extent to which they will suffer is however dependent upon may parameters and modeling assumptions.

\footnotetext{
${ }^{30}$ Note that in the presence of two monopolies, coordination of prices will suffice. With competitors in either market, pricing coordination will not suffice as some of the benefit of lower prices in one market will accrue to competitors in the market. Bundling is then necessary to make sure that the stimulation of demand in the second market accrues to the firm selling the two items.

31 This effect was first pointed out by the $19^{\text {th }}$ century French economist Antoine Augustin Cournot (18011877). Cournot analyzed the effect on prices of merging producers of complementary products, for example, copper and zinc used to produce brass in his illustration (see Cournot, 1838). He found that if two monopoly producers of complementary products coordinated their pricing via a merger, not only would the aggregate price of the products fall, but the combined corporate entity would increase both revenues and profitability. Cournot's model involved two monopolists producing single products and selling to a fragmented customer base producing brass.

32 This issue will be further discussed below.

${ }^{33} \mathrm{GE}$ went to substantial lengths to show that it was not free to act without regard to competitors or customers. However, ironically if the parties had monopolistic positions, the result on consumer welfare of the merger would have clearly been positive via an increased consumer surplus (see Nalebuff, 2003) - i.e. in the simplistic Cournot model - price for consumers would simply fall and stay at this lower level.
} 
These effects also rely on the assumption that firms set a single price for their products. Yet, there are no list prices in the aerospace industry. Very powerful buyers, Boeing, Airbus and the airlines individually negotiate prices. Meanwhile, the vendors themselves have significant information about the buyers' preferences. Both of these factors aid price negotiations, which precede the sale of products. In those circumstances, bundling is obviously less attractive. It does not help in terms of reducing the heterogeneity of buyers facing a single price, as individual prices are set for each deal. In addition, it does not help in terms of exploiting the Cournot effect: firms will not obtain additional rents from stimulating demand across products simply because competitors (who also negotiate with the individual buyers) will force the price down to their marginal cost on individual components. All the firm can obtain is the rent associated with customers' particular preference for each of its product, whether they are bundled or not.

In those circumstances, the transfer of profits from competitors to GE is small, as the buyer already had a preference for GE products which limited rivals sales. Moreover, bundling has the least effect where rivals are the preferred supplier for both engines and avionics products. Where the buyer has a preference for one GE product and the other from a rival, it is unlikely they will choose the bundle, as there is substantial evidence that components are chosen on a "best of breed" basis.

Hence, the consequences of mixed bundling are highly dependent upon particular circumstances, and a stylized economic model can hardly provide conclusive evidence. Both the models presented to the Commission by Frontier Economics and Professor Jay Pil Choi ${ }^{34}$ on behalf of Rolls Royce and by Professor Barry Nalebuff ${ }^{35}$ for GE are highly stylized and they have not even been calibrated to actual data. For example, the Rolls Royce model only has 2 competitors and 2 products. Whether there is actually an economic incentive to bundle in the aerospace industry can hardly be inferred from these exercises, nor can buyer and competitor responses and the possible losses to competitors. To model bundling realistically, one needs to know the number of items in the bundle, the total market demand elasticity, the preferences of each customer, the supplier's degree of awareness of these preferences and how much these preferences are likely to shift over time due to exogenous shocks (Nalebuff, 2003). Estimates of these parameters are naturally surrounded with much uncertainty (and all the more so because their development needs to be anticipated). When the US authorities examined these same issues they found that "such conduct is best addressed if and when it occurs, rather than ex ante, at the time of the merger when we have none of the facts we would need to determine whether the conduct, if it even occurs, would in fact be anticompetitive"(Kolasky, 2002).

Bundling: The Practice: This leaves us to examine current practice. The Commission put forward evidence that Honeywell had engaged in bundling, backed up by evidence from Rockwell Collins. However, in its decision to clear the Honeywell AlliedSignal merger, the Commission's case team found that bundling was not a widespread practice

\footnotetext{
${ }^{34}$ Professor of Economics, Michigan State University.

${ }^{35}$ Professor of Economics, Yale School of Management.
} 
in the avionics and non-avionics markets. ${ }^{36}$ They found that the characteristics of the industry are such that bundling is difficult. This was because:

1) As stated above, there are no list prices for products and transactions are individually negotiated. Buyers choose the best product on technical specifications.

2) The procurement process is long.

3) Concentrated and powerful buyers are able to play sellers off against one another.

4) Suppliers regularly re-price all products over a 2 month period.

The Commission stated that Honeywell had engaged in a number of multi-product bids which were bundles by another name. However, the bundle discounts were small (Nalebuff, 2003), and customers were able to break-up the packages, picking "best of breed", whilst still able to retain the bundle discount. Therefore, if bundling was taking place, it clearly was not very effective in displacing buyers away from competitors.

The Commission presented confidential evidence of a number of "multi-product bids" by Honeywell, which they claimed proved that despite the hurdles, bundling is possible. In the original decision (see pages $127-130$ ), the Commission gives a number of examples such as a bid for a US airline by AlliedSignal, where extended warranties were offered for purchasing two products together. We are not told by the Commission what AlliedSignal's competitors were offering, the value of the extended warranties or if the bid was successful (in whole or in part), so it is almost impossible to draw any conclusions from this example. One other example is offered, where more products were offered in a bundle, although again the value of the discounts is not made clear, nor whether the bundle was purchased in whole or in part. ${ }^{37}$

The above examples relate to large commercial jet aircraft. The Commission goes on to present examples of bundling in the area of corporate jets. In one example, the airframer requested a bundle for non-avionic components, having already selected Honeywell as the avionics supplier. Again, the facts are limited, and we are not informed of the outcome. Subsequent investigation by the authors demonstrates that although, according to the Commission, the manufacturer requested a bundle for non-avionics systems including ECS, APU, electrical systems and wheels/brakes, the firm was not successful in selling the entire bundle. ${ }^{38}$ While Honeywell was chosen to supply the ECS and APU, Hamilton Sunstrand (UTC) supplied the electrical system and ABSC the brakes/wheels. This example would seem to demonstrate the industry practice of unbundling bundles, and selecting components on a "best of breed" basis, whilst retaining substantial discounts.

\footnotetext{
${ }^{36}$ The unit of the Merger Task Force headed by Enrique Gonzalez Diaz which investigated GE/Honeywell was different from the one that dealt with Honeywell/AlliedSignal. In the US the same DoJ team dealt with both.

${ }^{37}$ One is tempted to presume that if these "multi-product bids" had been accepted by the airlines, the Commission would make it very clear that this was evidence that bundling was being practiced in the aerospace market. As it stands, these cases are forwarded as evidence that "bundling is feasible" (page 127).

${ }^{38}$ Source: Confidential correspondence with the manufacturer - on file with author.
} 
Ultimately, the Commission only presents one case, of a mid-size corporate jet, in which bundling (admittedly of engines and avionics) can be said to have taken place successfully.

Moreover, the complaints of 2 rival components manufacturers, UTC and Litton, maintained that bundling didn't take place. ${ }^{39}$ The EC also omitted vital evidence from Embraer, other OEMs and 5 airlines stating that bundling didn't occur. Airbus gave evidence that it breaks down all components and examines each on its merits. Also Boeing and Bombardier require bids to be itemized. Airbus's policy is to maintain "dynamic competition". In fact, its CEO Noel Forgeard stated in a letter to the Commission that the company did not oppose the transaction, and that GE/HW were important, but not dominant, and competitors were gaining ground. He went on to state that Airbus own strategies could deal with any anti-competitive threats should they arise. $^{40}$

Ignoring this evidence, the Commission goes on to speculate that the merger would then allow GE to bundle engines with avionics and non-avionics components. However, where GE is a sole source engine supplier, for example on the Boeing 737, the customers negotiate the purchase of the plane with Boeing, giving GE no room to attempt to bundle other components. ${ }^{41}$ Moreover, on multi-source platforms, the engines are chosen a significant period before the avionics and non-avionics components. Again, this makes it impractical to bundle. ${ }^{42}$ While GE could offer a subsequent discount on avionics, this is a problematic process, since the subsequent pricing of components is not based on official price lists, but is negotiated. As Nalebuff (2003, pg 37) states, "all prices are negotiated so a discount off the list price has no bite. One person can't promise to give the other party a better deal in future negotiations, as there is no baseline against which to measure what makes a better deal."

However, even if bundling becomes a common future practice, the Commission takes no account of strategic counter moves by competitors. For example, even if competitors were reluctant to offer counter-bundles, possibly due to the negotiating hurdles relating to which partner would cut prices more or unwillingness of current managers to give up power in a merger, it is likely the market would require them too (i.e. negotiations with Boeing and Airbus would effectively concentrate their minds, as may their institutional

\footnotetext{
${ }^{39}$ Source: Oral arguments at $25^{\text {th }}$ May 2004 Honeywell hearing in Luxembourg.

${ }^{40}$ In a breach of procedure, the Airbus letter was never revealed to the parties or the Commission's advisory committee prior to the decision. The summary of the letter above is based on the limited contents revealed during the appeal hearings at the Court of First Instance. The Commission has argued that the contents of the letter were manipulated by GE. As evidence they point to Forgeard's admission in the letter that from Airbus position, "remedies could be negotiated", as heavily indicative of the strength of their case (Source: Interviews with Merger Task Force Team members).

${ }^{41}$ As stated above, Boeing pre-negotiated an engine pricing deal with GE to protect its customers (Nalebuff, 2003).

${ }^{42}$ The Commission presents some evidence that selection timelines are flexible enough to allow bundling to take place. However, again the only conclusive example is the mid-size corporate jet, for which Honeywell bundled avionics and engines.
} 
shareholders) ${ }^{43}$ The end result of competition between bundles, again assuming bundling is economically viable, would be unambiguously good for customers and consumers. Such an outcome may have driven Airbus endorsement of the deal.

It is also important to note that even if competitors would not offer counter bundles, the extension of the product line over which bundling occurs, while increasing the attractiveness of bundling, would also reduce the extent to which competitors would be affected. Indeed, bundling can then easily lead to an increase in all prices. That may not be attractive from the point of view of consumers but indicates that the Commission's concern, that competitors would be marginalized, would become irrelevant. This observation further emphasizes that the presumption such that competitors would be marginalized is not robust and accordingly cannot be presumed.

After the publication of its Statement of Objections on May 8, 2001, the Commission began to downplay the bundling arguments, instead relying on a broader theory of Archimedean Leveraging. ${ }^{44}$

\section{Archimedean Leveraging:}

The role of GE's aircraft leasing company, GE Capital Aviation Services (GECAS) is at the heart of the final decision to block the merger. This division of GE engages in a number of transactions with airlines. A large percentage of its business relates to leaseback agreements, whereby airlines sell planes they already own to GECAS and then lease them back. These transactions improve airline balance sheets, and create tax and depreciation benefits. However, GECAS has no influence over the choice of aircraft in the deals, as these have already been purchased by the airline. Therefore, the Commission concentrated on the speculative purchases of new aircraft by GECAS. This is where the leaser purchases planes for which it does not have a final customer. It then looks to lease these to airlines with short operating leases (usually 8-9 years, Emch (2003)). Such a transaction allows the airline to lower its risk profile and may be efficient because GE is better able to bear the risk. Ultimately, consumers may benefit.

Archimedean Leveraging:The Theory: As stated earlier, the Commission believed that substantial engine market share shifting to GE had been driven by GECAS "GE only" policy in the speculative purchase market. The EC also feared that this policy would be extended to Honeywell components, hence further transforming a leading market position into a dominant one, leading to or re-enforcing market foreclosure. This was a theory put forward by Reynolds and Ordover (2002) on behalf of United Technologies. This theory of "pivotal" or "Archimedean" leveraging is built around the following elements; assume

\footnotetext{
${ }^{43}$ It's an interesting question as to whether the Commission should concern itself with the fates of managers who forego pro-competitive, value enhancing mergers at the expense of shareholders, to retain there own positions. Moreover, it is ironic, as Kolasky (2002) points out, that the Commission downplays the effectiveness of joint ventures as a competitive response, whilst describing in detail how the CFMI JV between GE and SNECMA has been so successful.

${ }^{44}$ This switch in emphasis was criticized by the Financial Times. "More than once Commissioner Monti allowed his officials radically to shift ground for their objections, creating the unfortunate impression that EU anti-trust policy was being made on the hoof." (Hill and Done, 2001).
} 
that a firm is present both as a supplier of components to manufacturers (Airbus/Boeing) and as a buyer (GECAS) of final products from these manufacturers. This buyer is, however, not a final user of the products. It packages the aircraft with a financing scheme and sells the packages to final users (airlines). Final users can alternatively buy the aircraft themselves and obtain financing from different sources (these alternatives being substitutes for one another). Assume further that the manufacturers choose the components (hence, components are supplier furnished equipment - SFE - or embedded) and a single brand of component is selected for each model produced by the manufacturer (choices of components are once and for all and exclusive). Finally, assume that final users are rather indifferent to the choice of the component made by the manufacturers (in other words, there is little product differentiation among them).

Consider the purchasing policy of the integrated firm. Faced with two aircrafts sold at the same price, one with its components and one with other components, it will naturally choose the former, as a purchase of this product will also increase the profit of its affiliate, unless of course, its choice triggers changes among other buyers which reduce demand for its components. More generally, faced with a given price for the aircraft, the integrated company will choose to charge a lower price towards airlines for its bundle as it has a higher margin on each aircraft sold (unless there is a compensating change in the behavior of other buyers). ${ }^{45}$ Hence, the integrated firm will have a higher demand for aircraft (at a given price of the aircraft) if they include its component. Assuming that the price of financing airlines can obtain when they organize their own is fixed, aggregate demand increases.

Consider now the behavior of the intermediate manufacturers. In the absence of integration between a buyer and an upstream component supplier, it would select components solely in terms of prices. Faced with an integrated firm, manufacturers will as indicated above, face a larger aggregate demand for their product. Hence, they will find it more profitable (at given prices for the components) to produce an aircraft which includes the component of the integrated firm ${ }^{46}$ Prices for the components however, need not be constant; one would indeed expect that the competitors will charge a lower price. Assume, to fix ideas, that the integrated firm does not change its price (an assumption which is favorable to the competitors). In order to convince manufacturers to choose their components, they would have to charge a price which compensates manufacturers for the increased sales which are triggered by the choice of the component produced by the integrated firm. Given the value of the components relative to that of the aircraft, they may not be in a position to do so.

As told, the theory of "pivotal" leveraging relies on extreme assumptions and in particular the assumption that components are not differentiated. In those circumstances, even a small presence of the integrated firm as a downstream buyer will change the behavior of the manufacturer. This assumption, at least in such extreme form, is probably not consistent with the facts; it implies, in particular that the prices of the

\footnotetext{
${ }^{45}$ This is, in essence, a Cournot effect again, as the integrated firm considers an external effect across complements (components and financing).

${ }^{46}$ And may also increase the price of the aircraft.
} 
components should be driven to marginal cost. Given the importance of fixed costs in the development of components, this would in turn imply that firms make losses in the component market, which cannot be an equilibrium situation. The question then arises to what extent "pivotal" leveraging still operates when there is some product differentiation in the component market. Product differentiation will clearly reduce the extent to which the choice of component will be affected by integration (moving away from this would otherwise be an optimal choice and will be costly for the manufacturers) but should not annul it altogether, and it makes integration less attractive but not necessarily unprofitable. Pivotal leveraging also works in the example above even if the integrated firm has a small presence in the downstream market. At the extreme, any shift in aggregate demand can tilt the choice of the manufacturer. When there is some product differentiation among components, the magnitude of the shift, and hence the market presence of the integrated firm in the downstream market, will matter. Hence, whether pivotal leveraging can work in more realistic circumstances, is inherently an empirical question. At the same time, the specificity of this construct is such that it can hardly be presumed.

In order to give some credence to pivotal leveraging, the Commission considered the effect that GECAS had with respect to the choice of engines. Engines are typically not supplier furnished (embedded) and hence do not fit with the assumptions of the model underlying pivotal leveraging, but the Commission found it informative. Indeed, if GECAS was able to substantially shift purchases of buyer furnished equipment like engines, one would expect that it would a fortiori be in a position to do so with a SFE. In the context of BFE, suppliers will not be exclusivity upstream. The integrated firmcan nonetheless affect the relative position of these suppliers through its own purchasing policy, like a GE only policy for engines fitted on aircrafts bought by GECAS.

Archimedean Leveraging:The Practice: Some debate first arose with respect to the market share of GECAS. As Gotz Drauz, (then head of the merger task force) (2002, pg 194), states in his subsequent defense of the decision, "GECAS is the largest purchaser of new aircraft, ahead of any individual airline and or other leasing company. GECAS is also reported to have the largest single fleet of aircraft in service, as well as the largest share of aircraft on order and options". However, he neglects to mention GECAS low market share in a fragmented and competitive market.

The EC states GECAS market share as approximately $10 \%{ }^{47}$. However, Nalebuff (2003) argues that this overstates the figure. He gives evidence that it is closer to $7 \%$ over the last 5 years as GECAS aircraft purchases are irregular, and it often has to clear a backlog. In dollar terms GECAS market share is below 6\%, as a third of its fleet are regional aircraft (which are 30\% - 50\% cheaper than narrow body large commercial aircraft). Overall, other leasers accounted for $16 \%$ of the market, and the airlines approximately 77\%. (See graph in Appendix 3). If you determine market share via engine purchases between 1996 and 2000, GECAS is in second place behind International Lease Finance

\footnotetext{
${ }^{47}$ The $10 \%$ figure relates to both the large commercial and large regional jet aircraft markets.
} 
Corporation (ILFC), which is owned by AIG. ${ }^{48}$ Even if you attribute a $50 \%$ plus market share in engines to GE, it would be extremely hard to tip the market with GECAS 6\% $10 \%$ market share, although not necessarily impossible.

Moreover, this is before factoring in the dynamic behavior of leasing competitors which, although fragmented, have twice GECAS market share. Then there are also the competitive responses of engine and aerospace component rivals, the air-framers and airlines. Therefore, the Commission failed to undertake an equilibrium analysis.

Evidence has also been put forward that leasing competitors have moved away from GE engines. In calculating market shares, you should only include platforms where GE/CFMI competes head-to-head with other engine manufacturers. This excludes the Boeing 737 for which GE/CFMI is the sole supplier, and the Boeing 757, where customers can only choose between Rolls Royce and Pratt \& Whitney engines. In the period after GECAS started making speculative purchases of large commercial aircraft (1996 to 2000), GE/CFMI's engine market share to leasing companies actually fell from $52.3 \%$ to $50.6 \%$ on competitive platforms. Overall GE's market share did increase, but this was based on the fact that the leasing market expanded rapidly in the late 1990's, and so leasing companies market share compared to that of airline purchases also expanded (from $13.5 \%$ to $28 \%$ ). Many airlines chose to lease rather than buy outright. ${ }^{49}$ Ultimately, one transaction substituted for the other.

However, on competitive platforms, GECAS leasing rivals clearly shifted their purchases away from GE, so on balance GE's share of sales to leasers fell slightly (i.e. the "GE only" policy did not deliver enough extra engine sales to cover the strategic shift away from GE by competitors). ILFC, GECAS largest rival dramatically altered its purchases of GE engines on competitive platforms. It dropped these from 58\% in $96 / 97$ to $25 \%$ in 98/99. Overall, from 1996 to 2000, all GECAS leasing rivals dropped their share from $53 \%$ to $29 \%$ (Source: GE/Nalebuff submission to the Commission). The US DoJ found similar evidence of rivals shifting away from GE (see Kolasky, 2002, page 18).

All of this conflicts with the evidence presented by Reynolds and Ordover, who present 2 control groups (scheduled airlines and leasers). They find that in the airline group, GE engine purchases fell from $50 \%$ to $45 \%$ from 1996, while in the leaser group they rose from $40 \%$ to $60 \%$. Firstly, the control groups encompass wide and narrow body commercial aircraft (while large regional jets are mixed in with some of the calculations as Emch (2003) points out). The model assumes that other factors affecting orders such as pricing, aircraft quality, availability and commonality issues have no bearing, and are static over time. Moreover, as noted above, it fails to recognize that airlines are customers in both groups, and constantly substitute between buy and lease decisions. Thus, airlines leasing GE powered planes rather than purchase them outright cannot be counted toward share shifting (see Nalebuff (2003) and Emch (2003)). Overall, the only evidence that can

\footnotetext{
${ }^{48}$ American International Group (AIG) is one of the world's largest insurance companies with a current market capitalization of $\$ 185$ billion (21 June, 2004).

${ }^{49}$ It should also be noted that the late 1990's witnessed the rise of low cost carriers, which relied on leasing a greater number of their planes.
} 
be found is that GECAS has been able to increase the number of GE powered planes leased by smaller airlines ${ }^{50}$. The period over which this increase occurred also witnessed the rise of low cost carriers across the globe. If GE is leasing planes to many of these (particularly on shorter leases), one cannot also exclude that it is the result of GE's superior ability to manage these risks.

As indicated earlier, the Commission also fails to mention that there are legitimate strategic reasons for a "GE only" policy for engines. These include confidentiality and publicity issues surrounding purchases from rivals. Moreover, Nalebuff, GE's economic advisor states that the policy allows GECAS to differentiate itself from leasing rivals via product mix. Such a policy has clearly been accelerated by leasing competitors, and such non-price competition is positive from the industry perspective. The evidence above shows that while GECAS is "GE only", ILFC and other leasing competitors have leaned toward Rolls Royce and Pratt \& Whitney in recent years.

To provide further evidence of market tipping toward GE, the Commission also highlighted the Large Regional Jet (LRJ) market, and cases of 3 manufacturers, Bombardier, Embraer and Fairchild Dornier, who had chosen GE as sole engine supplier on their LRJ platforms. This is admittedly a situation which is closer to the assumptions of the model underpinning pivotal leveraging, as engine choices are in this case once, for all and exclusive. GECAS has placed large aircraft orders with all 3 companies in $2000 .{ }^{51}$ However, the Commission neglected to mention that GECAS only started making speculative purchases of LRJs well after the engines had been selected. For example, the Bombardier engine was selected in 1994, Fairchild Dornier in $1998^{52}$ and Embraer in June 1999. GECAS only received board approval to make speculative purchases, based on two independent studies of the LRJ market, after June 2000. ${ }^{53}$ These findings were backed up by the US Department of Justice investigation which examined each deal in detail (Kolasky, 2002). Their investigation found that in the early 1990's no currently available engine was suitable for the next generation of Large Regional Jets. GE took a gamble by producing a larger version of its CF 34 engine. This ultimately paid off when the market for LRJs turned out to be larger than expected. Fairchild Dornier and Embraer rushed to enter the market, where GE had the only readily available engine.

As indicated above, the Commission feared that pivotal leveraging would take place with respect to Honeywell components, hence further transforming a leading market position into a dominant one, leading to or re-enforcing market foreclosure. Such pivotal leveraging would first hardly be profitable in the case of non exclusive buyer furnished equipment. Indeed, the cost of an exclusive Honeywell policy would be large: for GE to

\footnotetext{
${ }^{50}$ Most of the share shifting was to small scheduled and non-scheduled airlines who required narrow body planes, not the major carriers. Narrow body aircraft equaled $81 \%$ of leasing companies orders (1988 to 2000). (Emph, 2003).

${ }^{51}$ GECAS bought 50 LRJs from each, with an option for 100 more.

52 The Fairchild Dornier Large Regional Jet was cancelled when the Company went into bankruptcy postSeptember $11^{\text {th }} 2001$.

53 After evidence of this was presented in the hearing pre the statement of objections, an affidavit from a United Technologies executive who had previously worked for one of the LRJ manufacturers, had to be withdrawn (source: Welch and Byrne (2001)).
} 
do this, they would have to jeopardize tens of millions of engine and leasing profits to gain tens or at most hundreds of thousands of dollars of components profits. The end customers for speculative purchases have some power. If GECAS buys aircraft with lots of components that customers don't want, it will hurt its own business model as it is likely to be left with planes on its books that nobody wants, as customers can easily go to ILFC which also engages in speculative purchases. As discussed above, it is also highly debatable whether GECAS has actually been able to successfully shift significant engine market share, and it is not clear it would have been easier in the component market. It is worth noticing from this perspective that there are no aircraft that have all Honeywell components (Nalebuff, 2003).

With respect to embedded exclusive components, the Commission received substantial evidence from Airbus, Boeing and Bombardier that they choose avionics and nonavionics components on "best of breed" technical specifications. In fact, the Reynolds and Ordover (2002) model does not take product differentiation or mix into account in direct contradiction to the evidence presented by the airframe manufacturers. ${ }^{54}$ As mentioned above, if components were undifferentiated, it begs the question of how the manufacturers sustain their margins over time, and why they reinvest into R\&D for the next generation of components. If these facts were indeed true, then with or without the GE Honeywell merger, a number of suppliers would likely be heading out of the components space (either via bankruptcy or acquisition). This was one of the findings of the DoJ's outside economics expert Marius Schwartz of Georgetown University, which led them to dismiss the model. ${ }^{55}$ The Reynolds and Ordover model also ignores the fact that airframe manufacturers face switching costs from their current preferred component suppliers, which are a mixture of Honeywell and other competitors. This would also indicate that the products are differentiated.

\section{The Role of GE Capital:}

Another fundamental element of the EC's case, allied with the bundling and GECAS arguments, related to GE Capital (GEC). This is the financial services division of General Electric, which accounted for $40 \%$ plus of GE's earnings at the time. ${ }^{56}$ Drauz, in his

\footnotetext{
${ }^{54}$ The Commission implicitly admits products are differentiated, arguing that competitors would be disadvantaged in future competition because, due to market tipping, they would lack R\&D funds to produce future components that would be sufficiently differentiated from competitors. In fact, the only evidence the EC presents for this is the evidence of a Honeywell competitor, Rockwell Collins. As noted above, the Company claimed that it would be forced to exit from either its avionics or non-avionics product lines. The same evidence was given to the US authorities, although clearly dismissed by them. This might have been based on the fact that, according to Jack Welch (2001), "competitors were viewing the European review process as a way to extort a goodie bag of Honeywell assets." Interestingly, Thales, a French avionics competitor who had lobbied strongly against the deal in Brussels, withdrew its complaints from the appeal process when divestiture was obviously no longer an option.

${ }_{55}^{55}$ Sources: Emch (2003) and interview with Marius Schwarz, May 2004.

${ }^{56}$ The Commission points out that if GE Capital were an independent company, it would be in the top 20 of the Fortune 500. GEC's revenue contribution has subsequently fallen due to acquisitions including Universal from Vivendi and Amersham. A secondary benefit of the Honeywell acquisition for GE, was that it decreased GEC's revenue/earnings contribution (from approximately $40 \%$ at the time). In fact, the
} 
reiteration of the Commission's arguments (2002, pg 193) characterizes GE as "a rather unique company", and GE Capital was part of "GE's toolkit for dominance" which would be extended to Honeywell. As GE retains a triple AAA credit rating lowering the cost of capital, the Commission argued that this allows it to "take more risks in product development programs" (Drauz, 2002). Moreover, by providing increased investment and competition in the aerospace market, GE has also "increased its competitor's needs to resort to external financial means further raising their leverage and resulting borrowing costs, GE made its competitors - most of which are specialized single- product companies - very much vulnerable to any down cycle or strategic mistake" (Drauz,2002). GE Capital's strengths allow GE to provide "significant financial support" to airframe manufacturers, and obtain exclusivity for GE engines.

The Commission's approach here can be seen as an "efficiency offense", as it expresses concern about the consequences for competitors of GE's low cost of capital, which presumably reflects the GE's efficiency in investing internal funds. Low cost of capital was indeed seen by the US authorities as a "source of efficiency, just like any other valuable asset, be it machinery, knowledge or management skills. Cheap capital serves to lower prices and promote innovation". (Platt Majoras, 2001). As Kolasky (2002) states, "this is the first time I remember seeing a triple AAA bond rating treated as an anti-trust no-no" (page 14). Implying that a firm's cost of capital is too low is quite a novel approach, since the main beneficiaries of low costs are most often consumers.

We further discuss below the source of GE's efficiency in investing internal funds and the extent to which the efficiency of Honeywell's operations could have been increased. In what follows, we focus on the possible anti-competitive consequences of an improvement in Honeywell's efficiency. In particular, the Commission suggests that Honeywell's competitors would face higher borrowing costs.

From this perspective, it is worth noticing that a number of GE and Honeywell's competitors are beneficiaries of state guarantees ${ }^{57}$, a fact which is overlooked by the Commission. For example, Thales, the French avionics manufacturer which was one of the most vocal opponents of the deal in Brussels, ${ }^{58}$ is a publicly listed company controlled by the French government thorough its shareholding and golden share (see Appendix 4). The latter mechanism has been ruled in violation of European law by the

Commission mentions this fact (paragraph 241), and seems to imply that GE was not being effectively regulated.

"US banking organizations are generally required by law to be operated in a "safe and sound" manner and are subject to extensive regulation, supervision and periodic examination by the relevant regulatory authorities that for example restrict them to strict lending restrictions/prohibitions on transactions involving affiliates."

However, one would think that these were issues for the US banking and financial markets regulators, rather than European anti-trust authorities.

${ }^{57}$ This is clearly not the case of GE, as much of its low cost debt stems from deploying its triple AAA rating in the highly liquid US Commercial Paper markets. See GE 2002 Annual Report: Consolidated Financial Statements: Note 18 at - http://www.ge.com/ar2002/financial/notes/note18.jsp

${ }^{58}$ See Welch and Bryne (2001). 
European Court of Justice. ${ }^{59}$ Therefore, the firm receives, at the very least, an implicit government guarantee of its debt, which at the time was triple A rated. Moreover, Boullion Finance, a leasing competitor, is a Seattle based division of West LB, the German Landesbank, which has benefited for a decade from illegal state guarantees and subsidies ${ }^{60}$.

In addition, Kolasky (2002) states that in the DoJ's investigation of the deal, "empirically, what we found when we examined the markets in which GE already competes, was that GE's engine rivals are both investing just as heavily as GE in developing their next generation of engines and have had no difficulty in raising capital to finance that effort."

\section{Horizontal Issues and Vertical Restraints:}

Having based the main tena nts of its case on "portfolio or range effects", the Commission returned to the more conventional anti-trust territory of horizontal effects and vertical restraints. It found horizontal overlap in large regional and medium corporate jet engine markets and power systems. The EC also highlighted issues of vertical restraints related to Honeywell's role as the sole manufacturer and supplier of component engine starters to Rolls Royce. GE and Honeywell forwarded a number of divestiture remedies, which obviously became irrelevant when the Commission blocked the merger based on portfolio effects. However, the important question remains as to why the US anti-trust authorities did not seek similar remedies on these horizontal and vertical issues.

Conflicting market definitions: Thrust vs. Seats: The reason the US Department of Justice found no horizontal overlap in the engine market for Large Regional Jets, was that it segmented it via the thrust power of the engines on the various platforms, as opposed to the number of seats and costs used by the EC. ${ }^{61}$ Therefore, the US authorities divided the market between platforms that utilized engines with thrust power below and above 9000 lbs, which require significantly more expensive high temperature materials to manufacture. The net result of such an analysis shows that Honeywell does not manufacture engines larger than $7000 \mathrm{lbs}$ thrust, and therefore has no horizontal overlap with GE. All GE engines have 9000 lbs of thrust plus, and do not compete head-to-head with Honeywell on any platform (See Appendix 2 for a complete breakdown of each category by manufacturer, aircraft model, engine type and thrust, which demonstrates the lack of overlap between General Electric and Honeywell). ${ }^{62}$

\footnotetext{
${ }^{59}$ See Case C-438/99: Commission vs. France, Case C-367/98: Commission vs. Portugal and Case C503/99 Commission vs. Belgium, Commission of the European Communities vs. the United Kingdom (2003): C-98/01.

${ }^{60}$ Also at this time, the EC approved a $\$ 364 \mathrm{~m}$ British government loan to Rolls Royce. (see "EU Approves Rolls Royce Loan" at http://news.bbc.co.uk/1/hi/england/1628264.stm).

${ }^{61}$ Background information from author interviews with Bill Kolasky, former Deputy Assistant Attorney General and interviews with the merger parties and advisors, Washington DC, March 2004..

${ }^{62}$ It should be noted that this includes the corporate jet engine category, where GE's sole model has 9,220$18,500 \mathrm{lbs}$ of thrust.
} 
The Commission acknowledged that thrust was an issue for regional jet engines, whilst providing no information on the characteristics of the various engines. "In relation to large regional jet aircraft, engines for such types are not substitutable to engines for smaller regional jets. This is due to the different thrust power that these two categories of engines are required to deliver". (pg 8) However, this leaves the anomaly of the Avro LRJ, which the EC used to base its argument on horizontal overlap and is now out of production. The Avro is the only large regional jet (based on the Commission's definition of $70-100$ seats), which uses the Honeywell ALF507 engine with thrust power of 7000 lbs. All other LRJs listed by the Commission, for whom GE supplies engines, utilize thrusts of $9000 \mathrm{lbs}$ plus. Uniquely, the Avro uses four smaller engines, and it is physically impossible to fit $2 \mathrm{GE}$ engines onto the airframe. The Commission tried to back up its argument with reference to aircraft prices. The figures showed that the catalogue price of the Avro is less than that of a narrow bodied large commercial aircraft. However, it also demonstrates that it's about $10 \%$ more expensive than comparable LRJs. ${ }^{63}$

\section{An Efficiency Defense?}

The Commission also claimed that GE had failed to present any efficiency gains from the merger, and therefore that this allowed them to rule out that the merger would strengthen the company's market position through efficiencies that ultimately benefit consumer welfare. Enrique Gonzalez Diaz, head of the investigative team examining the deal has stated, "the merging parties are not claiming, let alone quantifying, any type of efficiencies". ${ }^{64}$ However, the failure of GE to present and quantify efficiencies is disputed. Jack Welch states in his biography - "I felt we could do so much more with Honeywell's assets by doing what we've done with GE: pushing more aggressively into services, and adding Six Sigma and e-business initiatives to Honeywell's operations. We figured on $\$ 1.5$ billion in savings from these initiatives and other productivity measures" (Welch and Byrne, 2001, pg 362).

It appears however that GE did not formally invoke an efficiency defense of the deal itself. This is partly because they did not believe that the deal was anti-competitive in the first place, for many of the reasons stated above. In addition, at the time of the deal, whether an efficiency defense existed in European law was ambiguous. ${ }^{65}$ In 2002 , the Competition Commissioner, Mario Monti, explicitly recognized the existence of an

\footnotetext{
${ }^{63}$ The higher price point of the Avro may be due to its "niche" characteristics, which make it particularly suited to landing at hot and high altitude airports with steep approaches and climb-outs. The EC dismisses any distinction of the Avro on this basis, since some European airlines use Avro's to fly to airports without these characteristics - e.g. Sabena (now Brussels Airlines) to Brussels National Airport. This begs the question of why any airline would pay more for an aircraft with characteristics it did not need! Commission officials have subsequently pointed out that this may be associated with substantial discounting, although in turn this raises the question of whether it is efficient to give away extra "niche" features on a plane that the customer has no need of.

${ }^{64}$ Comments in Roundtable Discussion, Antitrust, Fall 2001.

${ }^{65}$ Motta (2000), states that this ambiguity was the intention of European legislators (particularly the Germans and the British) who feared that the French would put forward such a defense to justify anticompetitive mergers among their companies. Others have speculated that there may have been an efficiency offence in Europe (Kolasky, 2002/ Patterson and Shapiro, 2001). See Drauz (2002) for a vigorous rebuttal.
} 
efficiency defence for the first time, by stating that Article 2(1)(b) of the Merger Regulation provides a clear legal basis (see Monti, 2002) ${ }^{66} \mathrm{He}$ went on to state that such efficiencies "would have to be of direct benefit to the consumer, as well as being merger specific, substantial, timely and verifiable ${ }^{67}$." Still, one can wonder about the nature of efficiencies and why, unlike the DoJ, the Commission chose to ignore them?

It seems that GE's efficiencies involve two distinct issues, namely whether as a conglomerate GE can be expected to allocate capital efficiently, and whether GE could be expected to generate particular efficiencies from the combination of its assets with those of Honeywell.

\section{Internal capital markets}

Regarding the allocation of capital, history is littered with examples of conglomerates which utilized "cheap" capital from their treasuries to subsidize weak divisions whilst foregoing higher value investment opportunities, and ended up destroying billions of dollars in value. The conglomerate mergers of the 1960's and 70's were generally shown to be unprofitable (see Ravenscraft and Scherer, 1989), and were ultimately broken up in the 1980's. A significant body of academic literature has grown up examining the failings of internal capital markets (see for example the work of Scharfstein and Stein, 1997).

For an internal capital market to work efficiently, it must equalize its cost of capital with the market based cost for similar projects based on their risk profile. Only then can a conglomerate assign capital to internal projects effectively, and know their true opportunity cost. It would appear that GE's internal capital market operates along these lines. The Company employs a strong financial budgeting discipline to avoid the mistakes of previous US conglomerates. The firm's lower cost of funds is matched by higher return expectations. All project funding is subject to significant competition internally. Internal rates of return hurdles are high. Welch (2001, pg 232) describes one of the screening processes in his autobiography - "potential deals are put through a monthly torture chamber. The meetings are hands-on, no-holds-barred discussions among some 20 GE insiders with more than 400 years diverse experience." The same logic applies with respect to mergers and acquisitions, with strong pressures and boundaries on management. ${ }^{68}$ The DoJ concurred in its investigation, finding that "GE has many other uses for its capital and committing capital to one project entails opportunity costs because that capital is no longer available for other, perhaps more worthwhile, projects. Taking these opportunity costs into account, GE's cost of capital, with respect to any particular project, should be equal to that of its competitors." (Platt Majoras, 2001). Therefore, it looks as if the Commission did not appreciate GE's effective use of funds.

\footnotetext{
${ }^{66}$ Article 2 (1)(b) states that the Commission shall take account, inter alia, of "the development of technical and economic progress provided it is to consumers' advantage and does not form an obstacle to competition".

${ }^{67}$ The new merger regulation has also clarified this.

${ }^{68}$ An example of an industry where these constraints are clear is entertainment. Before its acquisition of Universal, GE consistently walked away from deals in this area, including proposed ones with Disney and Sony, much to the frustration of NBC head Bob Wright. See Leonard (2003).
} 


\section{Dealing with Merger Synergies:}

The source of efficiency that GE anticipated with respect to acquisition of Honeywell, appears to be related to deployment of GE's intangible assets, in particular its organizational structures and procedures, which are describes by Welch as the Six Sigma initiative in his book. A number of case studies have highlighted these organizational and knowledge based techniques at GE - see for example Bruner (2004) on Corporate Development as a Strategic Capability in GE Power Systems ${ }^{69}$ and Ashkenas, DeMonaco and Francis (1998) on acquisition integration at GE Capital. ${ }^{70}$ It is clear from these case studies that GE has made large investments in its intangible assets, even in industrial businesses, and has been successful in scaling these assets in multiple acquisitions in all its business lines (the deployment of intangible assets as a source of efficiency in mergers is discussed in Box 1). Therefore, the firm can be seen as adding unique value to a deal, which is demonstrated to a degree in GE Honeywell, as General Electric was able to significantly outbid Honeywell's only other suitor, UTC. ${ }^{71}$ The efficiencies to be realized were not static ones (one off improvements in production possibilities), but dynamic ones, which build and diffuse knowledge across the organization increasing innovation and hence the production possibilities. The market reaction to the deal underlines this analysis (see next section), as markets are more wary of dynamic/revenue synergies than more traditional technical/cost cutting ones. ${ }^{72}$

Box 1. Synergies and intangible assets

Neven and Seabright (2003), develop an analytical framework for assessing the sources of merger gains within the context of competition regulation. They state that "firms engage in mergers and acquisitions because they anticipate that additional value will be generated by re-combining assets and that the sources of these gains must be found in the operation of intangible assets". The authors distinguish between physical assets such as capital and labour, and intangibles including skills, reputation, knowledge, organizational learning and structures. Lev (2001) emphasizes the scalability of intangible assets. Moreover, these intangible assets would have different values to different acquirers, so during the acquisition process, it is unlikely that an alternative bidder will emerge with similar gains.

Ultimately, firms that successfully combine intangible assets should produce higher returns. However, the difficulties of combining such intangibles as human knowledge and learning, as opposed to physical plants and machinery, will produce a greater variance in returns overall. Through the examination of a cross section of mergers, the authors demonstrate that there is a positive link between the share of intangible assets combined

\footnotetext{
${ }^{69}$ In 2001, GE Power Systems acquired 17 other firms.

70 The authors summarize that GE's organizational innovations stem from “dozens of experiments until they crystallized to a form a metho dology others could follow" (page 165).

${ }^{71}$ However, the deal included an option to buy $19.9 \%$ of Honeywell - a $\$ 9$ bn hurdle to ward off other suitors which might be thought unnecessary under the circumstances.

${ }^{72}$ The underperformance of GE could reflect the wariness of financial markets of pricing in future revenue synergies - the market would certainly be correct in this based on the empirical evidence presented by Neven and Seabright (2003).
} 
and the variance of returns - showing higher returns where deals have succeeded, but overall greater risk of value destruction.

Regulators should rightly be skeptical about synergies, which may be harder to evaluate than technical efficiencies and for which it may be harder to determine how much consumers will benefit, as the benefits are often in the form of new or enhanced products which do not exist yet. Neven and Seabright (2003) suggest that regulators should examine the firm's integration plans, mechanisms, incentives and previous track record. If such an approach had been undertaken in GE Honeywell, the investigation of these aspects would have likely weighed in GE's favour. ${ }^{73}$

This perspective is in line with that of the US DoJ, particularly in the assessment of conglomerate mergers in general. Platt Majoras (2001), states "We recognize ..... that conglomerate mergers have the potential as a class to generate significant efficiencies. These potential benefits include providing infusions of capital; improving management efficiency either through the replacement of mediocre executives or through the reenforcement of good ones with superior financial control and management information systems; transfer of technical and marketing know how and best practices across traditional industry lines; meshing of research and distribution; increasing ability to ride out economic fluctuations through diversification; and providing owner-managers with a market for selling the enterprises they created, thus encouraging entrepreneurship and risk-taking." Hence, it appears that US regulators recognize that conglomerate mergers are driven by a strategy of leveraging or scaling intangible assets such as organizational knowledge and effective control structures, the efficiency effects of which may beneficial for society. The EU did not follow the same approach.

\section{Market Reaction to GE Honeywell:}

Whilst it is debatable how much emphasis should be placed on stock market reactions to particular deals, it appears that the EU was confronted (in May 2001) with evidence on the market reaction to the GE Honeywell deal, but took no account of it. ${ }^{74}$ Hence, it may be useful to review these reactions.

Theoretically, when anti-competitive effects take the form of unilateral or coordinated effects, competitors will gain at least in the absence of efficiencies. When efficiencies are strong enough to compensate for anti-competitive effects, the deal will be procompetitive and competitors will be hurt (their profits will fall). Hence, in this environment, there is a correspondence between competitive effect and the change in the profit of competitors. With conglomerate effects, the correspondence is however lost, as competitors are typically hurt when the deal is anti-competitive ${ }^{75}$. Evidence that

\footnotetext{
${ }^{73}$ In an off-the-record comment, an individual involved in the US side of the case told one of the authors that past experience had lead the DoJ to view GE as one of the few firms whose estimates of efficiencies could be regarded as accurate.

${ }^{74}$ Testimony of Carl Shapiro and Greg Vistnes on behalf of GE, May $23^{\text {rd }} 2001$. The Commission was also supplied with share price analysis and a report on the financial strength of competitors from the Consultants Booz Allen Hamilton.

${ }^{75}$ See Duso, Neven and Roller (2003) for a detailed discussion.
} 
competitors gained is then a signal that the market did not anticipate strong conglomerate effects (but possibly more conventional ones).

In the GE Honeywell case, almost all the aerospace competitors witnessed significant gains in their stock prices and outperformed the market benchmark. In the engine competitors segment, both UTC and Rolls Royce outperformed the benchmark, as did avionics and non-avionics competitors Rockwell, L3 and Smiths. ${ }^{76}$ Such a reaction would not be expected for financially weak competitors, about to be driven from the marketplace. Moreover, both Boeing and Airbus parent company, EADS, out performed. In fact, one of the few companies to under perform its benchmark was GE (see Appendix 5). Therefore, the market gave a very different verdict from the Commission in relation to GE's ability to bundle complementary products and leverage its financial strength although it should be noted that Honeywell performed very well suggesting that its shareholders were gaining most of the benefits (rents).

The initial lukewarm reaction of equity analysts to the merger gives us some insight into the mind of the market. Deutsche Bank stated that the "fit is reasonable but not extraordinary .... (the) strategy (is) to provide "complete systems rather than individual components for airlines ..... However, we are not sure if this thrust, which is fairly common in the aerospace sector today, actually justifies the combination itself." The bank also talked of, "significant integration risk .... A repeat performance of the Honeywell AlliedSignal merger is clearly the risk here."

Merrill Lynch went further in quantifying the market's concerns in relation to the proposed merger of Honeywell with United Technologies, which GE broke up. The "market's response indicates that something else is at issue. We think that something else is the Honeywell AlliedSignal record .... Size, management issues and perceived risk would bother us."

“A significant amount of operating power will have to reside in Honeywell's management at all levels. UTC's management is terrific and tested, but we think that they cannot, on their own, run a company twice the size ..... Honeywell management has not performed. There is also the question of the pre-merger brain drain at AlliedSignal. Lots of managers left from 1996 - 99, and often, when they ended up running other companies, these companies did poorly quickly. This phenomena has resulted, we think, in the view among investors that there was something amiss at Allied. Perhaps, that the businesses and their managers had been pushed beyond their capacity to deliver consistently."

A subsequent Merrill Lynch equity research report on GE of August 31, 2001 sheds some more light on what the market was really thinking. Honeywell was a step-back for GE

\footnotetext{
${ }^{76}$ UTC rose $21 \%$ (11\% out performance) from October $16^{\text {th }}, 2000$ to May $18^{\text {th }}, 2001$. Rolls Royce gained $34 \%$ ( $24 \%$ out performance) over the same period, which reflects a timeframe in which the market believed the deal would be cleared in Europe. Of the component competitors, Rockwell rose 38\% (28\% out performance), L3 34\% (24\% out performance), Smiths 28\% (18\% out performance) and Thales $2 \%$ (8\% underperformance).
} 
because it was, "just a lot more of the cyclical slow-growing businesses which GE already has enough of .... the new team is just as happy not to have Honeywell which would have just gotten in the way". The authors also note that GE sold its aerospace division in the 1980's. They continue, “the history of GE's multiple seems to be that when investors sense something new is happening at GE that will make it a better company (cost cutting in the early 1980's, the initiatives in the 1990's), they ultimately award GE a higher value. For much of 2001, GE's stock has underperformed because investors seemed to sense that what GE was doing for itself (trying to buy Honeywell), was not such a great thing .... and the stock market was also weak during that time."

The equity research analysts who wrote the report had had 10 months to canvass institutional investor's views on the merger, and it is clear that the market was highly skeptical as to whether the deal conveyed any anti competitive advantages, and was in any way good for GE. 77

There are some mitigating factors here. Firstly, it is likely that the share price rallies of GE's competitors to an extent reflected future acquisition premiums. However, this fact undermines the Commission's argument that competitors could not muster strategic responses to the GE Honeywell combination via either mergers or joint ventures. ${ }^{78}$

Secondly, some of the pressure on GE's share price was a result of M\&A arbitrageurs shorting the stock. ${ }^{79}$ In relation to Honeywell, Deutsche Bank stated on December $12^{\text {th }}$ 2000, "Although we do not have an estimate of the number of shares in the hands of arbitrageurs, we know that there is at least a component and the number remains

\footnotetext{
${ }^{77}$ While the market had a clear view on the merits of the deal for GE, it had little insight into the Commission's decision making process. Honeywell's stock price only began to reflect concerns that the deal might be blocked from late May 2001. Deutsche Bank's commentary on the deal is a good example of this lack of insight:

$22^{\text {nd }}$ October, 2000 - "Our initial analysis suggests that any anti-trust issues to be minor (aircraft engines and polymers are 2 areas of overlap) to be easily addressable via (small) dispositions if necessary."

$3^{\text {rd }}$ May, 2001 - implies that after US approval that EU should be forthcoming, although perhaps with further remedies.

June $14^{\text {th }}, 2001$ - DB is still optimistic about EU, "approvable on both political and competitive merits". June $15^{\text {th }}, 2001$ - Then - "we now believe the deal is unlikely to close" - after submitting their letter, GE told the market that they believed the EU would not approve it. "We find ourselves unexpectedly sympathetic to Commissioner Monti's view. That is his surprise at the content of GE's letter. It looks like GE stopped negotiating."

${ }^{78}$ It is interesting to note that the only competitor which underperformed was Thales, a French company, insulated from institutional shareholder pressure by the fact the French government is the largest shareholder and retains extra powers via a "Golden Share" (see Appendix 4). This is in line with the findings of Grant and Kirchmaier (2004), which demonstrates empirically that widely held firms outperform those with dominant shareholders over the long term in Europe, and that States are the block holders which destroy the greatest shareholder value.

${ }^{79}$ Shorting entails a forward sale of stock. The seller sells an equity she currently doesn't own at the current price for delivery at a date in the future. She then has to buy the equity in the market to deliver it to the buyer. If the price has fallen before delivery, the seller makes a profit. If it has risen she makes a loss.
} 
significant." ${ }^{80}$ An economically rational parallel strategy, whilst going long on Honeywell, would have been to short GE. Such a strategy would minimize the arbitrageur's capital outlay (but not capital at risk). Essentially, the arbitrageur could deliver the GE stock she would have received when the deal closed, to cover the outstanding short position. ${ }^{81}$ Since the arbitrageurs would have bought Honeywell at a discount to the GE offer price (to compensate for the risk of the deal not closing), and theoretically the price of GE stock should fall further on closing, the arbs should have cleaned up on both GE and Honeywell. Instead, they were forced to dump Honeywell stock at a loss.

However, neither of these factors detracts from the strongly negative signals for GE stemming from the equities markets in relation to the deal, nor the fact that the Commission failed to consider them.

The EC has subsequently argued that issues of vertical foreclosure are too complex for markets to understand. Regulators have better information than market participants, as equity analysts rely on information fed to them by the firms they cover. ${ }^{82}$ Regulators have the legal power to collate a broader range of evidence, and therefore have access to data that markets don't have, for example in this case on multi-product bids. However, as indicated by the extensive review of equity research reports from the time of the deal detailed above, it is clear that the analysts had carefully considered the deal and were skeptical of revenue synergies, which could be associated with anti-competitive effects. In addition, it is not clear that the confidential evidence collated by the Commission, in particular multi-product bids would have modified the perception; as indicated above, this evidence is far from conclusive and the theories on which the Commission relied are controversial. Hence, it seems difficult to draw any conclusions about the relative outcomes of information asymmetries between markets and regulators ${ }^{83}$.

\section{Summing up}

Overall, one cannot help concluding that (i) horizontal effects rely on a particular perspective on market definition which is debatable (and leaves some questions unanswered), (ii) that anti-competitive effects in the bundling and archimedean leveraging theories cannot be presumed to say the least, and that their likelihood should accordingly be supported by strong evidence, although that evidence was far from compelling and (iii) that the deal may have involved significant efficiencies that were overlooked.

\footnotetext{
${ }^{80}$ In his autobiography, Former US Treasury Secretary and Goldman Sachs arbitrager, Robert Rubin, says "Asking about ... arbitrage operations is like walking into a couple's home and asking about their sex life" (Rubin, 2003).

${ }^{81}$ See simple model in Appendix 6 for the dynamics of such a transaction.

${ }^{82}$ Source: Interviews with Merger Task Force team members.

${ }^{83}$ A former economist at the DoJ Anti-Trust division expressed a clear presumption on this issue: "it boils down to whether you trust the agencies or the stock market. I'll take the stock market any day" (Bruce Kobayashi in Fortune Magazine, April 14 ${ }^{\text {th }}$ 1997) - Quote from Neven and Roller (2002).
} 
These observations indicate that the Commission did not meet the burden of proof ("very probable anti-competitive effects") that it should normally respect. It also suggest that the Commission's decision may have been affected by bureaucratic capture, such that civil servants did not follow the mandate that has been assigned to them. The final part of the paper reviews the procedure itself and discusses whether EU procedures are indeed more prone to bureaucratic capture and whether there is direct evidence supporting the view that capture did indeed play a significant role in the case.

\section{Part 3: Process and Procedure}

Commentators have highlighted the differences between the processes and procedures on either side of the Atlantic, as another important element in explaining the divergence of outcomes in this case (see for example Patterson and Shapiro, 2001). ${ }^{84}$ These authors suggest that significant differences existed at the time of the investigation due to the fact that the European system is a "regulatory process", and the American system is a "law enforcement" one. This crucial difference, along with differing perspectives on the role of economic evidence, may have played a part in determining the outcome. It has also been suggested that these process and procedural differences "tend to amplify differences in substance" (see comments of John DeQ Briggs - Roundtable Discussion - Antitrust, Fall 2001, page 7).

Kühn (2003) also discusses particular features of the European procedure (at the time of the case). He highlights the role of economists (or lack thereof) and the fact the process of investigation by the Commission is subject to a self confirming biases. The standard to review which is applied in case of an appeal must also play in important role in delineating the scope for capture. We discuss these elements in turn.

\section{Standard of review in court}

The extent to which civil servants will be able to pursue objectives that are different from those that they have been assigned and, for instance prohibit a merger with weak evidence, is clearly dependent on what, they expect, will happen at the stage of appeal. If they anticipate that an appeal is unlikely and/or that Court will not scrutinize their ruling, they will benefit from greater freedom and the scope for capture will be greater.

At the time of GE Honeywell the legal appeals process to the European Court of First Instance took a minimum of 18 months to 2 years. Monti (2001) stated, "It is true that the decisions of the Courts take a long time (around 2 years) and that the merger will probably be abandoned by that stage". ${ }^{85}$ This delay gives further power to the Commission to direct the outcome without independent oversight (as well as improving the negotiating position of the EC in relation to immediate remedies ${ }^{86}$ ).

\footnotetext{
${ }^{84}$ Patterson was lead antitrust counsel for GE in the US, and Shapiro was one of GE's economic experts.

${ }^{85}$ This was indeed the case in Airtours vs. The Commission (2002). This can be contrasted with the Oracle/Peoplesoft prohibition by the DoJ. This merger was blocked on February 26, 2004. The appeal trial began before the US District Court for the Northern District of California on June 7, 2004. A decision was handed down by Judge Vaughan Walker on September 10, 2004, a timeframe of just over 6 months.

86 "Parties negotiating a settlement with the EC have limited bargaining power, companies negotiating with the DoJ know that a judge ... will decide on the injunction US companies enjoy a better situation
} 
The standard of review applied by EU Courts in merger case has been subject of much debate following the annulment by the CFI of Airtours/First Choice, Tetra Laval/Sidel and Schneider/Legrand mergers. Interestingly, the Commission appealed the Tetral Laval/Sidel ruling to the Court of Justice, precisely on the issue of the standard of review. In essence, the Commission argued that the appropriate standard should be one of "manifest error" and argued that CFI had applied a stronger standard, in particular one in which the Court considered whether the evidence was "convincing" and substituted its own economic assessment for that of the Commission.

The Court of Justice in its ruling on this appeal effectively confirms the decision of the CFI. The Court indicates that a proper standard of review should include a control of the economic assessment undertaken by the Commission. This control should include, in particular, whether facts substantiate the conclusions, and this evaluation will naturally include a discussion of whether the economic theories used by the Commission are robust. The Court ruled in particular (§ 39) :

"Whilst the Court recognises that the Commission has a margin of discretion with regard to economic matters, that does not mean that the Community Courts must refrain from reviewing the Commission's interpretation of information of an economic nature. Not only must the Community Courts, inter alia, establish whether the evidence relied on is factually accurate, reliable and consistent but also whether that evidence contains all the information which must be taken into account in order to assess a complex situation and whether it is capable of substantiating the conclusions drawn from it. Such a review is all the more necessary in the case of a prospective analysis required when examining a planned merger with conglomerate effect."

And further, at $\S 41$ :

"Although the Court of First Instance stated, in paragraph 155, that proof of anticompetitive conglomerate effects of a merger of the kind notified calls for a precise examination, supported by convincing evidence, of the circumstances which allegedly produce those effects, it by no means added a condition relating to the requisite standard of proof but merely drew attention to the essential function of evidence, which is to establish convincingly the merits of an argument or, as in the present case, of a decision on a merger."

Hence, it would appear that the Commission may have anticipated that the standard of review that would be applied in case of appeal would be relatively easy to meet. This may have contributed to the scope for capture.

\section{Role of Economists and Economic Reasoning:}

when negotiating with the agencies than European companies when negotiating with the EC" (Baches Opi, 1997). 
The US DoJ has a much larger professional staff and employs over $50 \mathrm{PhD}$ economists. At least one is attached to each case, and cannot be removed from the case team. The Economic Analysis group is organized in parallel to the legal group. The latter group breaks down along industry lines with 6 sections. The Economics group is more flexible with 3 sections - each section has a Section Chief and Assistant Chief. The economists on the case teams report to the Section Chiefs, who in turn report to the DoJ's Chief Economist. Their work is reviewed by both their Section Chief and the legal Section Chief with industry expertise - in essence double checked. ${ }^{87}$ This structure also allows the merging parties to engage in constructive dialogue with the DoJ economists including external ones.

Within the European Commission structure, economists have not played a central role as in the US. One EC economist stated that you are a civil servant first, then an economist. The Competition Directorate has, until recently, not had the position of Chief Economist, unlike the US, so economists have had to ultimately report $\mathrm{b}$ a non-economist. In GE Honeywell, the Commission made no attempt to create its own economic models, rather it relied "heavily on economic models supplied by competitors opposing the deal" (Shapiro and Pattersen, 2001). When flaws in these models were pointed out, it then claimed in the final decision "reliance on one or the other model not necessary for its conclusions."

The Commission hired its own economic expert, Professor Xavier Vives. ${ }^{88}$ However, the Commission dismissed him when he stated his misgivings about the case. Vives criticized statements on foreclosure as "too strong", Rolls Royce exit scenario was "far fetched", and the Choi model, which had sellers as price setters and buyers as price takers, as incorrect in aerospace ${ }^{89}$. Such differences reflect both a lack of emphasis on economic reasoning in decisions, and the lack of immediate and informed third party scrutiny of such decisions.

\section{Regulatory Hearings and Courts:}

One of the major differences between the US and EU is that the DoJ must seek an injunction in a Federal District Court to block a merger, which may in fact lead to a full trial. DoJ will move to get a temporary restraining order at a preliminary injunction hearing within 10 days. If contested within 60 to 90 days there will be a trial on the merits. ${ }^{90}$ This immediately places a higher burden of proof on regulators, as the case will be publicly scrutinized by independent observers. The facts of the case will then be examined in a hearing, where the government and competitors evidence is crossexamined by the merging parties counsel under oath with clear rules of evidence and procedure. Beyond this the authorities face the prospect of a full public trial.

\footnotetext{
${ }^{87}$ Organizational information from interview with Bill Kolasky - Washington DC, February 2004.

${ }^{88}$ Professor of Economics, INSEAD.

${ }^{89}$ Information from Honeywell hearing at the Court of First Instance- May 25, 2004. The Commission responded that Vives was retained to examine selected issues, and left the project when his work was completed. However, this begs the question as to why Vives did not testify on the EC's behalf at the CFI.

${ }^{90}$ Procedural information from interview with Deborah Platt Majoras - Washington DC, February 2004.
} 
This contrasts starkly with European system of hearings, with independent judicial review by the European Court of First Instance (CFI) only occurring a substantial period after a decision has been reached (see Appendix 7 for overview of the European Court System). The EC process revolves around formal hearings during phases 1 and 2 of an investigation. However, Pattersen and Shapiro (2001) categorize these as resembling "seminars" rather than court hearings. Evidential standards during these hearings are not comparable with those of a court, with the merging parties having to defend themselves from both the Commission and competitors. The Commission case team plays the role of policeman, prosecutor, judge and jury, while the merging parties are forced to make their case and come up with solutions with little guidance, so end up arguing against/incriminating themselves (Welch). Power seems to lie almost exclusively with the case team. There is a Hearing Officer, but he has limited powers, and does not rule on the admissibility or weight to be accorded to the evidence or have any say in outcome. It was also unclear in the European regulatory process where the burden of proof lay, at this point. $^{91}$

This can be contrasted with the US process, which involves substantive review at each level, (both on fact and economics). This reflects the need to make final argument in court and larger number of economists on the staff. The parties in the US also have more interaction with the equivalent of the case team at each stage of the process (less structured and more informal).

According to Shapiro, "From the beginning of the investigation, DoJ staff engaged in an intense and productive dialogue with GE and Honeywell regarding the theory. GE and Honeywell had the opportunity to respond to both the DoJ's concerns and to the concerns and allegations communicated to the DoJ by others. Economists for the DoJ, including a specially retained outside economist, and the parties were closely involved in this process."

It is striking from this respect that Jack Welch was quite unaware of the problems he was going to face with the Commission. He recalls from a first oral presentation before the statement of objections was published ; - "I argued my case for an hour and thought I was making some progress. I built the argument around GE's European performance, its remarkable success energizing former state owned companies, its strong European presence with 85,000 employees, and the lack of overlap between Honeywell and GE. We offered non divestiture remedies, like those made earlier by Honeywell-AlliedSignal, to address any problems."

\section{Conclusion}

\footnotetext{
91 Even though in principle the Commission has the burden of proof, the regulatory nature of the hearings seems to place it upon the merging parties, at least after the Statement of objections. This contrasts with the US, where the burden of proof is clearly on the government to demonstrate that a transaction will adversely impact competition.
} 
Overall, it appears that EU procedures were at the time of the case vulnerable to bureaucratic capture. The recollection of the parties (subjective as they may be) also confirms that the actual procedures may not have allowed for a fair and constructive investigation and appraisal of the case. Finally, particular incidents like the dismissal of the Commission's economic expert raise the suspicion that procedure may have been manipulated. This evidence of the characteristics of the EU procedure, as well as the actual unfolding of the procedure in this case, resonate with the analysis above suggesting that the Commission's case rests on weak grounds. There is at least a consistent set of facts indicating that the case team was the victim of a self confirming bias or possibly may have pursued a different objective from that assigned by the merger regulation.

Since the GE/Honeywell prohibition, the Commission has undertaken significant reforms of its processes and procedures. This reform process began before GE/Honeywell, in July 2000, with the submission of the report to the Council of Ministers on the functioning of the Merger Regulation. Subsequently, a Green Paper was adopted in December 2001, and over 120 submissions were received over an 11 month period. However, the outcome of the reform process was clearly influenced by the EC's 3 court defeats, and the controversy surrounding the GE decision. Monti (2002) called for "changes, as radical as needed, to ensure that our merger investigations are conducted in a manner which is more thorough and more firmly grounded in economic reasoning." To this end, a new position of Chief Competition Economist was created within the Competition DirectorateGeneral, with a staff to "provide an independent economic viewpoint to decision-makers at all levels". ${ }^{92}$ Monti also committed to "accelerate the ..... recruitment of industrial economists .... and that greater use be made of outside economic expertise." Other "necessary improvements" included ensuring that "there is sufficient management oversight to deal with the Commission's full merger case-load, that the case teams are sufficiently large, and that they are equipped with the expertise necessary to cope with indepth investigations."

In terms of independent scrutiny of merger investigations, the Commission has set up independent Peer Review or Devil's Advocate Panels, to thoroughly examine a case team's conclusions during Phase 2 Merger cases. These provide a "fresh pair of eyes at key points in the enquiry. This will prevent that the natural tendency of all human beings of being convinced of their own arguments determines the outcome of our investigations." 93

The Commission has also enhanced the transparency of the process and the ability of the merging parties to defend themselves against accusations leveled at them by competitors. The parties now have immediate access to the Commission's files on initiation of an investigation, as well as constant access to third party (including competitor) submissions received throughout the process and the ability to attend "state of play meetings" to better

\footnotetext{
${ }^{92}$ This position was subsequently taken up by Professor Lars Hendrik Roller of Humboldt University in Berlin.

${ }^{93}$ It should be noted that after the Airtours decision and GE/Honeywell, Monte began to institute far greater scrutiny of the work of MTF investigative teams. For example, he unexpectedly cleared the acquisition of UK cruise operator P\&O Princess by Carnival of the US after "he had instructed another team of officers to sit in on the work of the officers handling the case, to act as skeptical arbiters" (Economist, Sept 21, 2002).
} 
understand how the case team's investigation is progressing. All of these measures better allow the merging firms to defend themselves at an earlier stage in the proceedings, not just when the EC has issued its statement of objections. Moreover, Monti called for the merging parties to be able to confront third party complainants in meetings "ideally held in good time before the issuing of a statement of objections".

Finally, in relation to Judicial Review, Monti acknowledged that it "should not only be effective in terms of substance - it must also be timely. There is clearly still some scope for improvements in the speed with which judgments are delivered, particularly in cases where the merging parties are keen to keep the deal alive pending the outcome of the appellate process." To this end, a fast track procedure has been introduced in the Court of First Instance, which places greater emphasis on oral proceedings, which now can deliver judgments within 9 months. ${ }^{94}$ As mentioned above, the Court has also recently clarified the standard of review that it will apply in merger cases. This should significantly enhance the burden of proof to which the Commission will subject itself.

All of these reforms certainly reduce the scope for bureaucratic capture even if they fall short of implementing a truly adversarial procedure. They also potentially increase the importance of economic analysis, even if the resources involved fall short of those found in the US. Whether these reforms will suffice will only be revealed by forthcoming cases (and possibly other instances of transatlantic conflict).

Finally, it is worth placing the reforms instituted by Mario Monte at the end of his tenure, in the context of the initial changes in the structure of the competition directorate at the beginning of his period of office. The primary aim of these was to insulate commission officials from political pressures stemming from member states, particularly in relation to anti-competitive mergers involving "national champions". Indeed there is evidence that pressure from member states did initially play a significant role in merger decisions (see Neven and Seabright, 2003). Although speculative in conclusion, we would suggest that the aim of the initial reforms was very much in the interests of non-EU firms receiving a fair hearing in Brussels. Ironically, the result left the EC's processes and procedures open to bureaucratic capture by Commission officials rather than member states.

\footnotetext{
${ }^{94}$ Both Tetra Laval and Schneider Legrand decisions were decided within approximately 9 months and 1 year under this procedure. It should be noted that GE did not request use of this fast track when appealing the Honeywell prohibition, partly because it felt that it may have truncated its ability to fully make its case.
} 


\section{BIBLIOGRAPHY:}

Ashkenas, R., L.J. DeMonaco and S.C. Francis (1998) "Making the Deal Real: How GE Capital Integrates Acquisitions", Harvard Business Review, January/February 1998.

Atkins, R, T. Bruck and H. Williamson (2004) "German Banks Close to EU Deal on Aid", Financial Times, September 22, 2004.

Baches Opi, S. (1997) "Merger Control in the United States and the European Union: How Should the US Experience Influence the Enforcement of the Council Merger Regulation", Journal of Transnational Law and Policy, 6, 1997.

Beath, J. and Y. Katsoulakos (1991) "The Economic Theory of Product Differentiation", Cambridge University Press, 1991.

Bruner, R. (2004) "Corporate Development as a Strategic Capacity: The Approach of GE Power Systems" in "Applied Mergers \& Acquisitions", John Wiley \& Sons.

Buck, T. (2004) “No Easy Way Out For Monti”, Financial Times, September 20, 2004.

Carney, B. (2001) "Loggerheads: Mario Monti, Central Planner”, Wall St Journal Europe, July 6, 2001.

Choi, J.P. (2001) "GE/Honeywell: A Model of Mixed Bundling", Submission to the European Commission, May 2001.

Cournot, A. (1838) "Research Into the Mathematical Principles of Wealth", James and Gordon, CA, 1995.

Department of Justice, (2001) "Range Effects: The United States Perspective", Antitrust Division Submission for OECD Roundtable on Portfolio Effects in Conglomerate Mergers. Available at www.usdoj.gov/atr/public/international/9550.pdf

DeQ. Briggs, J. and H. Rosenblatt (2001) "A Bundle of Trouble: The Aftermath of GE/Honeywell", 
Antitrust Law Journal, Fall 2001, Volume 16, No.1.

DeQ. Briggs, J. and H. Rosenblatt (2002) "GE/Honeywell - Live and Let Live: A Response to Kolasky and Greenfield”, George Mason Law Review, 10:3, Spring 2002.

Dombey, D. and P. Betts (2003) "State Aid Row Threatens Monti Legacy", Financial Times, September $10,2003$.

Drauz, G. (2001) "Unbundling GE/Honeywell: The Assessment of Conglomerate Mergers Under EC Competition Law", Ford Corporate Law Institute, New York.

Economist. (2002) "European Antitrust Policy: Competing Visions", September 21 - 27, 2002.

Emch, E. (2003) "GECAS and the GE/Honeywell Merger: A Response to Reynolds and Ordover", Department of Justice Economic Analysis Group Discussion Paper, EAG 03-13, August 2003.

Ferguson, N. (2004) "Colossus: The Rise and Fall of the American Empire", Penguin Books, London.

Fox, E. (2002) "US and European Merger Policy - Fault Lines and Bridges: Mergers That Create Potential For Exclusionary Practices", George Mason Law Review, 10:3, Spring 2002.

Grant, J. and T. Kirchmaier (2004) "Corporate Ownership Structure and Performance in Europe", Centre for Economic Performance Discussion Paper 631, London School of Economics, April 2004.

Hill, A. and K. Done (2001) “Going Home Alone”, Financial Times, June 18, 2001.

Kolasky, W. (2002) "Conglomerate Mergers and Range Effects: It's a Long Way From Chicago to Brussels", Speech Made Before the George Mason Symposium, Washington DC, November 9 2001.

Lindsey, A, E. Lecchi and G. Williams (2003) "Merger Control: Does the EU Practice What it Preaches", European Competition Law Review, December 2003.

Leonard, D. (2003) “The Unlikely Mogul”, Fortune Magazine, September 29, 2003.

Lev, B. (2001) "Intangibles, Management, Measurement and Reporting" The Brookings Institute Press, Washington DC.

Monti, M. (2001) "The Future of Competition Policy in the European Union”, Speech at Merchant Taylors Hall, London, July 9, 2001.

Monti, M. (2002) "Merger Control in the European Union: A Radical Reform", Speech at EC/IBA Conference on EU Merger Control, Brussels, November 7, 2002.

Nalebuff, B. (2003) "Bundling, Tying and Portfolio Effects: Part 2 - Case Studies" DTI Economic Paper 1, London, February 2003.

Neven, D. and L. Roller (2002) "Discrepancies Between Markets and Regulators: An Analysis of the First 10 Years of EU Merger Control", HEI Working Paper No. 10/2002.

Neven, D, L. Roller and T. Duoso (2003) "The Political Economy of European Merger Control: Evidence Using Stock Market Data", Working Paper.

Neven, D. and P. Seabright (2003) "Synergies and Dynamic Efficiencies in Merger Analysis", Final Report to DG ECFIN, August 2003.

Ravenscraft, D. and F. Scherer (1989) “The Profitability of Mergers", International Journal of Industrial Organisation, 7.

Reynolds, R and J. Ordover (2002) "Archimedean Leveraging and the GE/Honeywell Transaction" Antitrust Law Journal, 70:171, 2002.

Rey, P. and J. Tirole (2003) “A Primer on Foreclosure”, Mimeo, July 16, 2003.

Rubin, R. and J. Weisberg (2003) "In An Uncertain World", Random House Books, New York.

Patterson, D and C. Shapiro (2001) "Transatlantic Divergence in GE/Honeywell: Causes and Lessons", Antitrust Law Journal, Fall 2001, Volume 16, No.1.

Platt Majoras, D. (2001) "GE-Honeywell: The US Decision”, Speech Made Before the Anti-Trust Section of the State Bar of Georgia, November 29, 2001.

Schaferstein, D. and J. Stein (1997) "The Dark Side of Internal Capital Markets: Divisional Rent Seeking and Inefficient Investments", Mimeo, Massachusetts Institute of Technology.

Welch, J. and J. Byrne (2001) "Jack: What I've Learned Leading a Great Company and Great People", Headline Books, London. 


\section{APPEN DiCES:}

\section{Appendix 1: Aerospace Market Overview:}

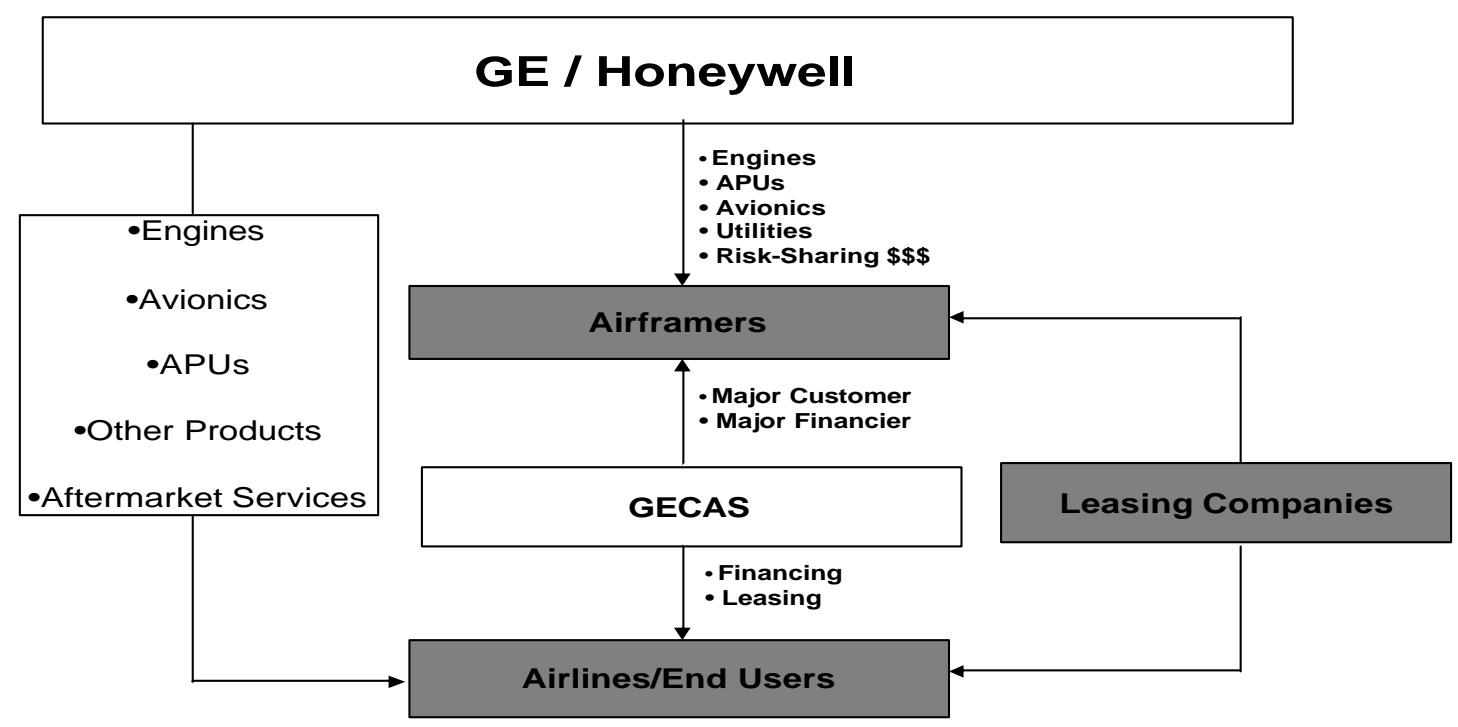

Source: Adapted from Diagram Presented by Rockwell Collins at CFI, Luxembourg, May 2004

\section{Appendix 2. Engine market overview}



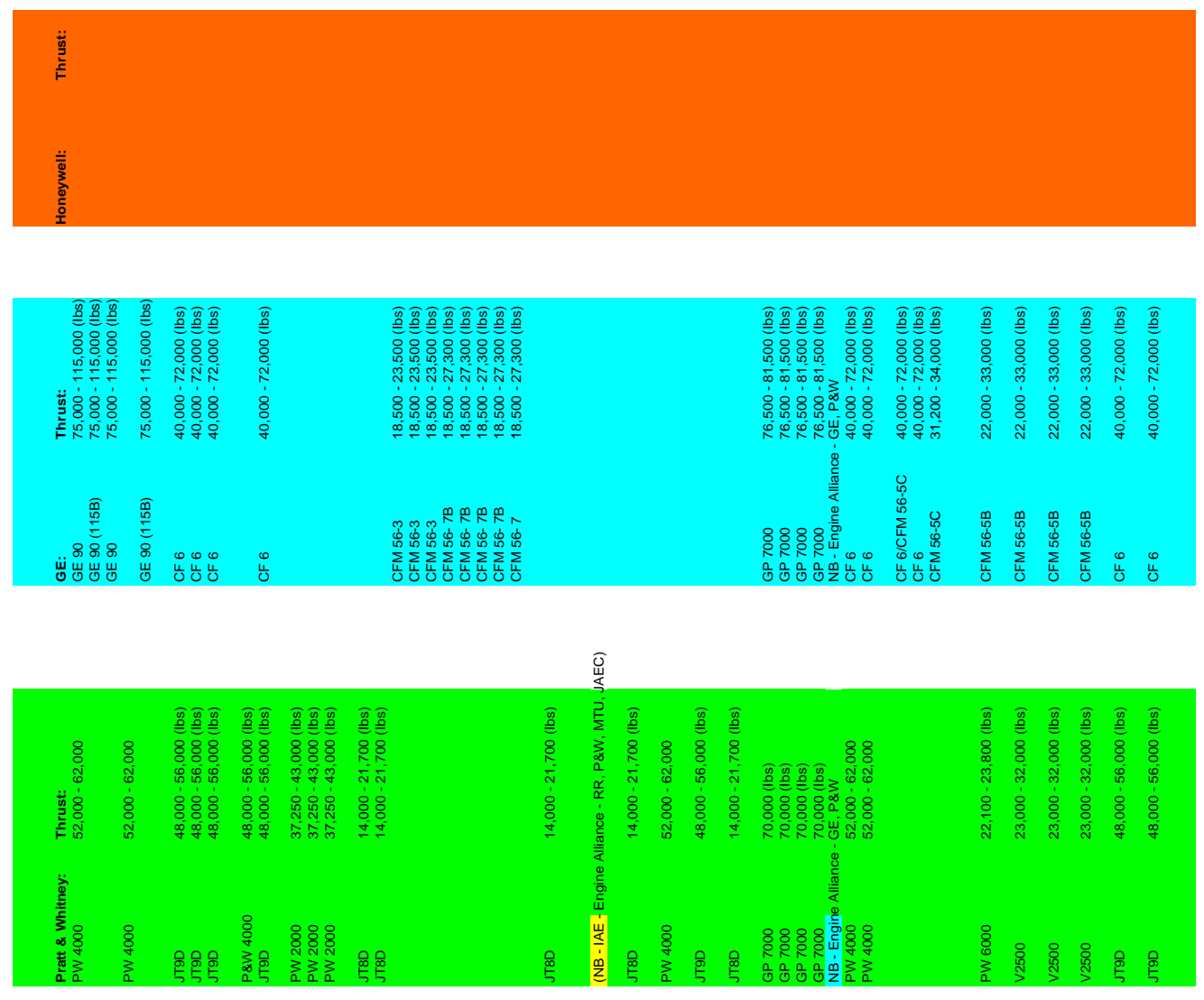

\begin{tabular}{|c|c|c|c|c|}
\hline 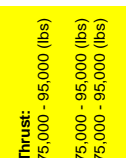 & 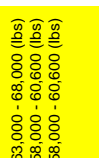 & 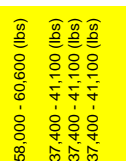 & 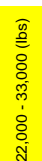 & 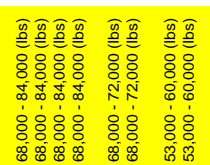 \\
\hline
\end{tabular}
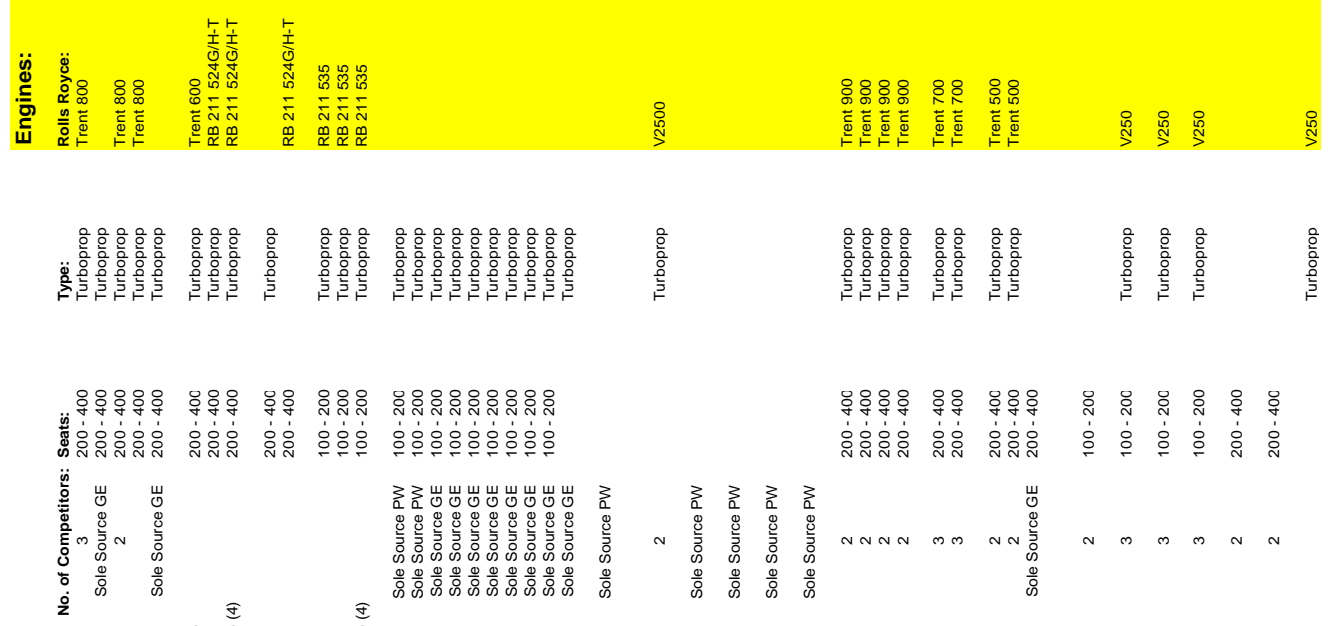

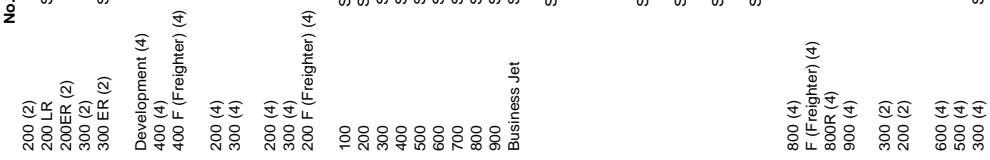

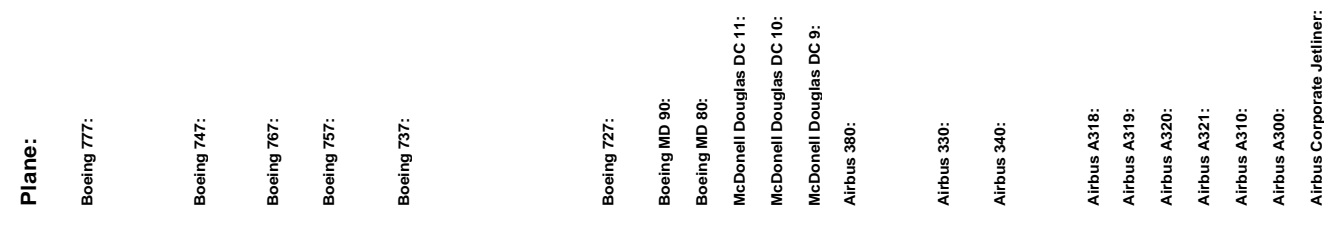



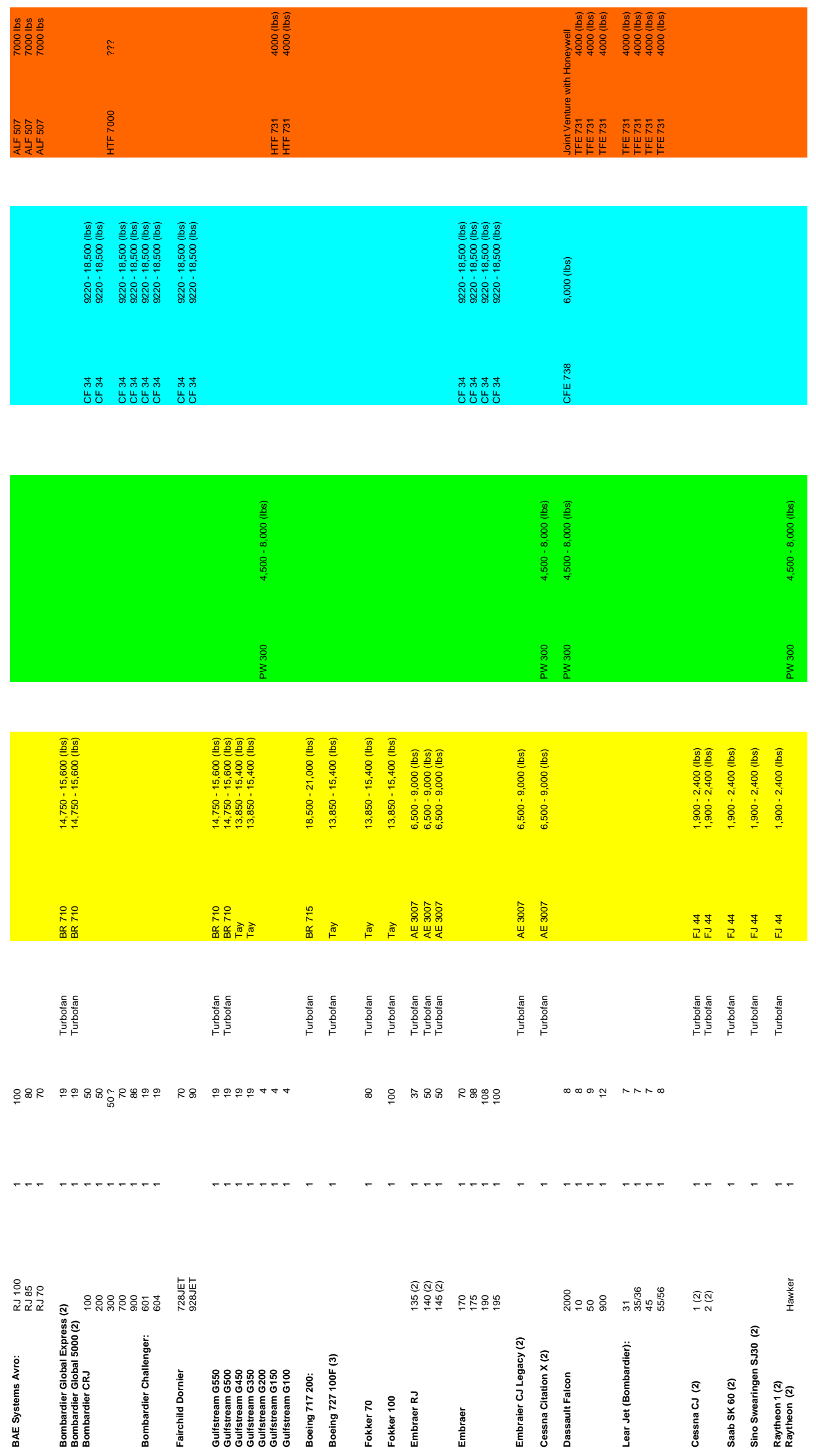


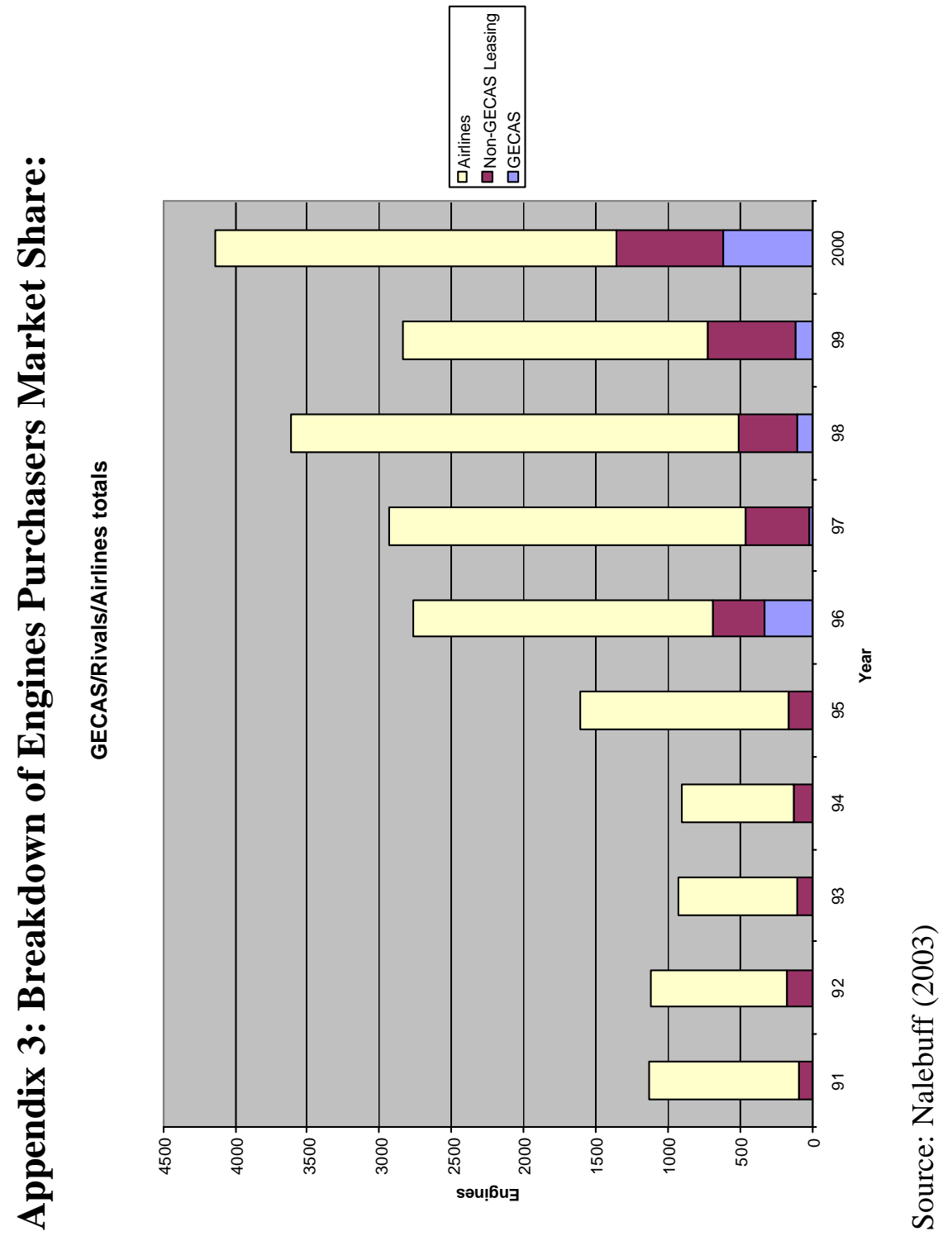




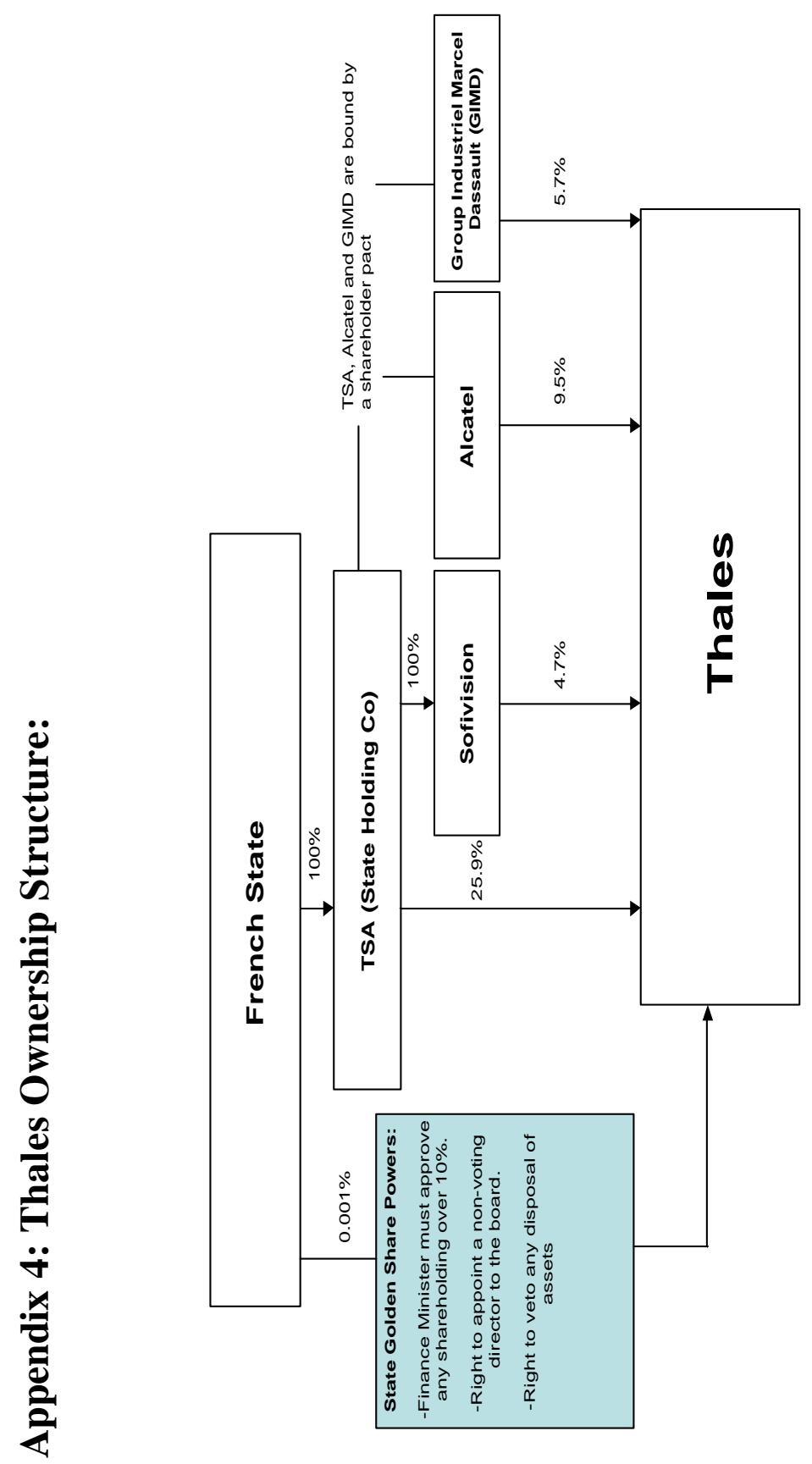

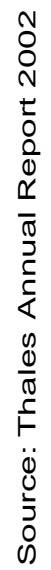




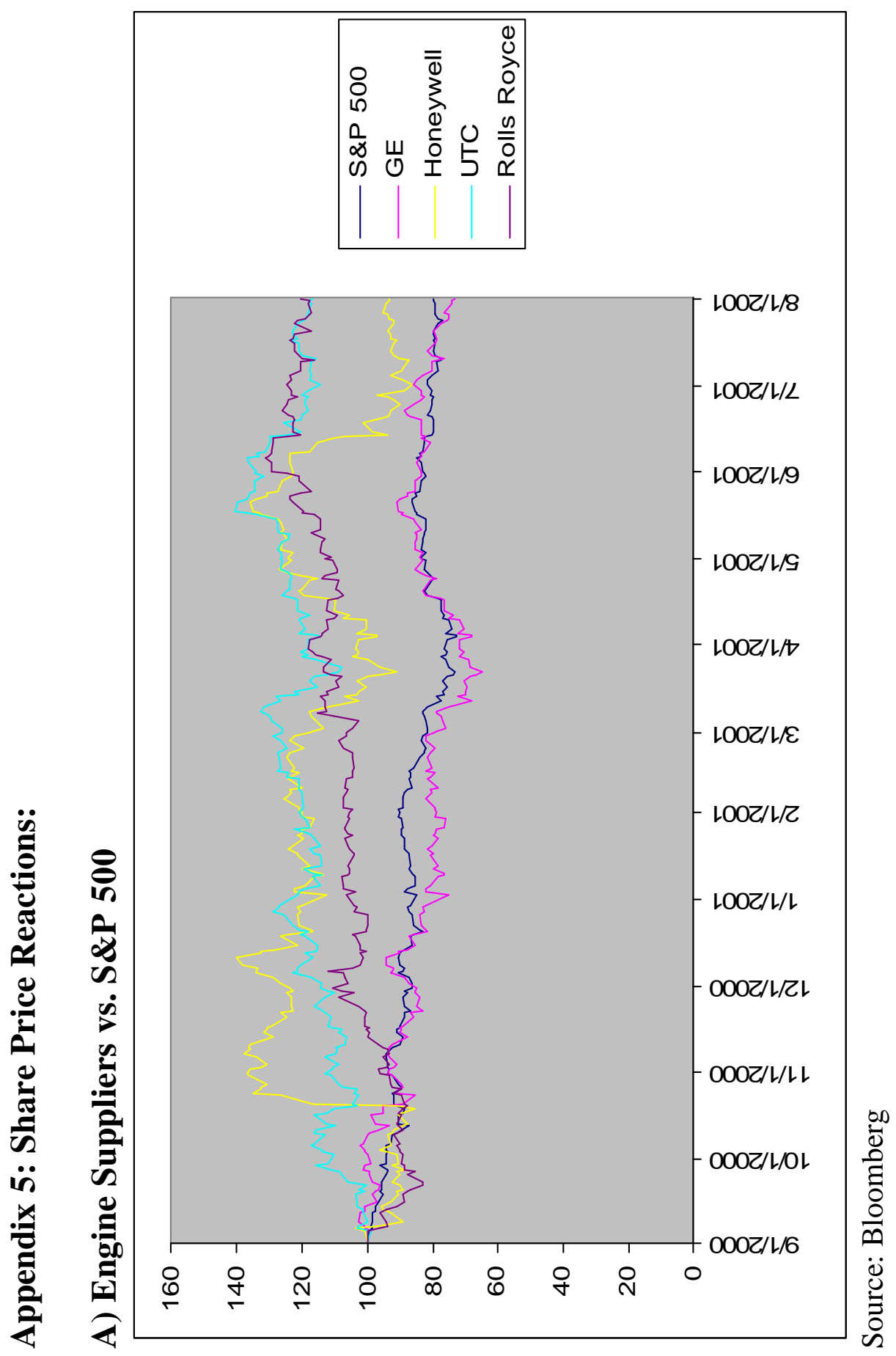




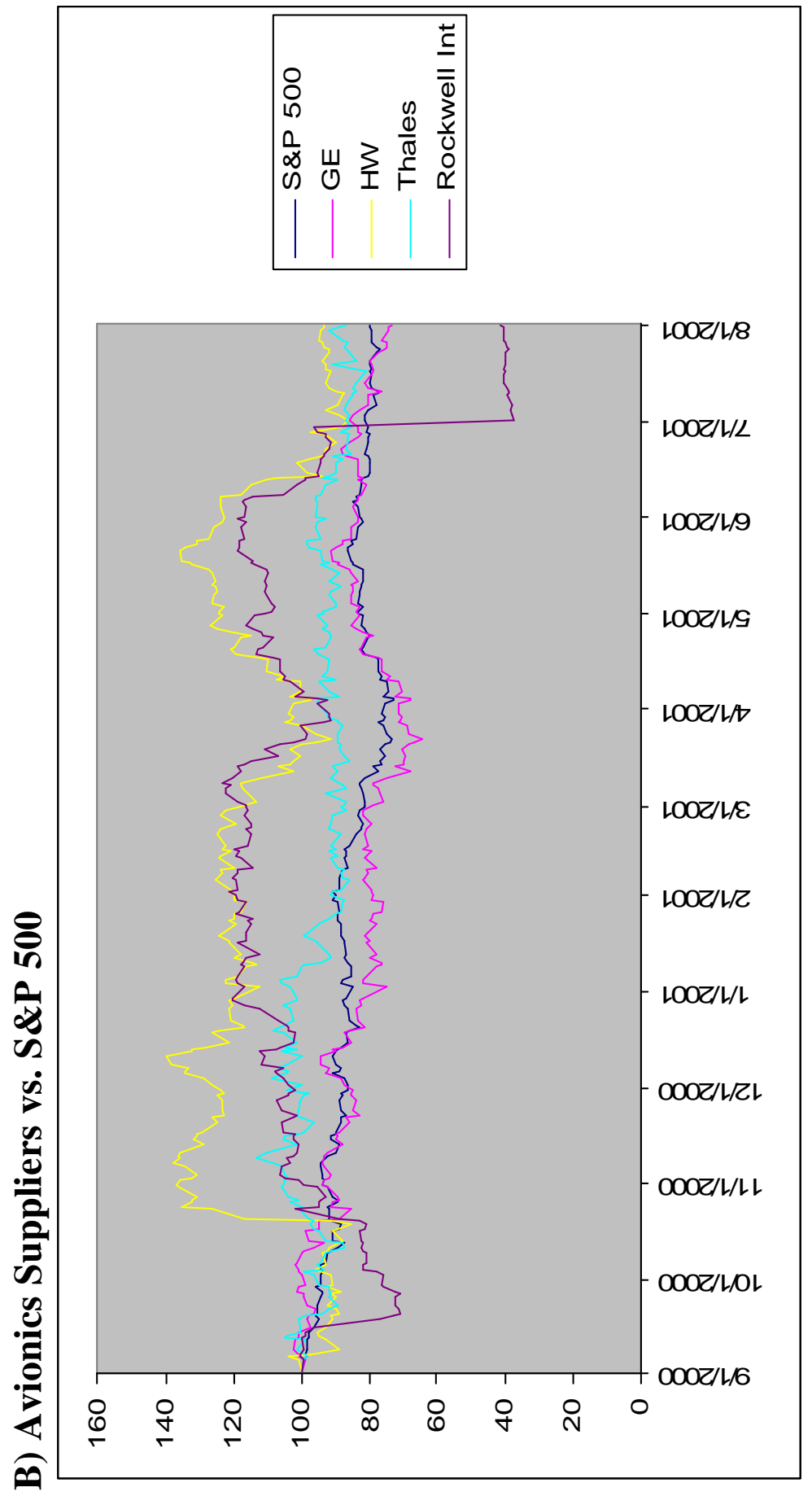




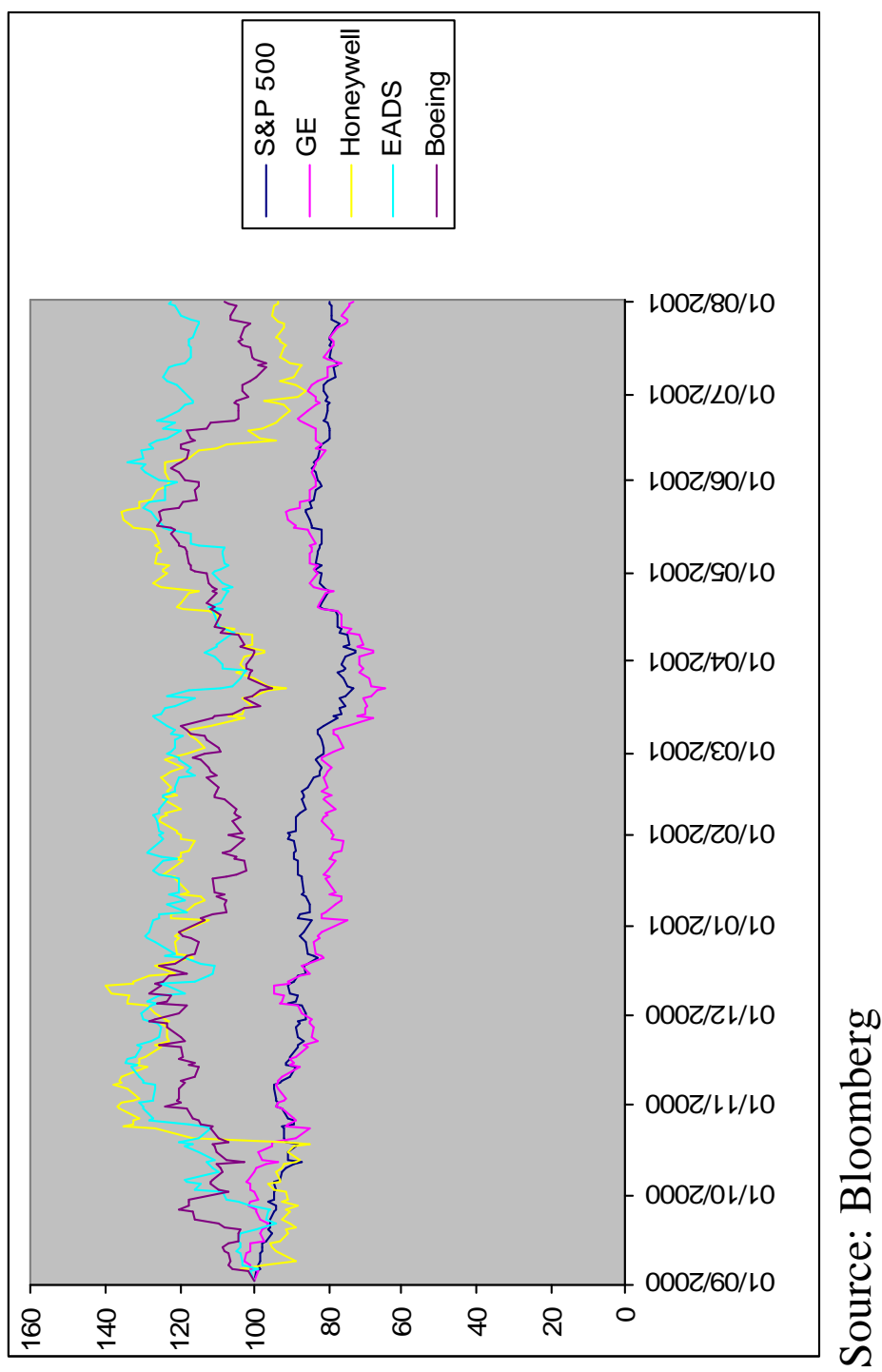




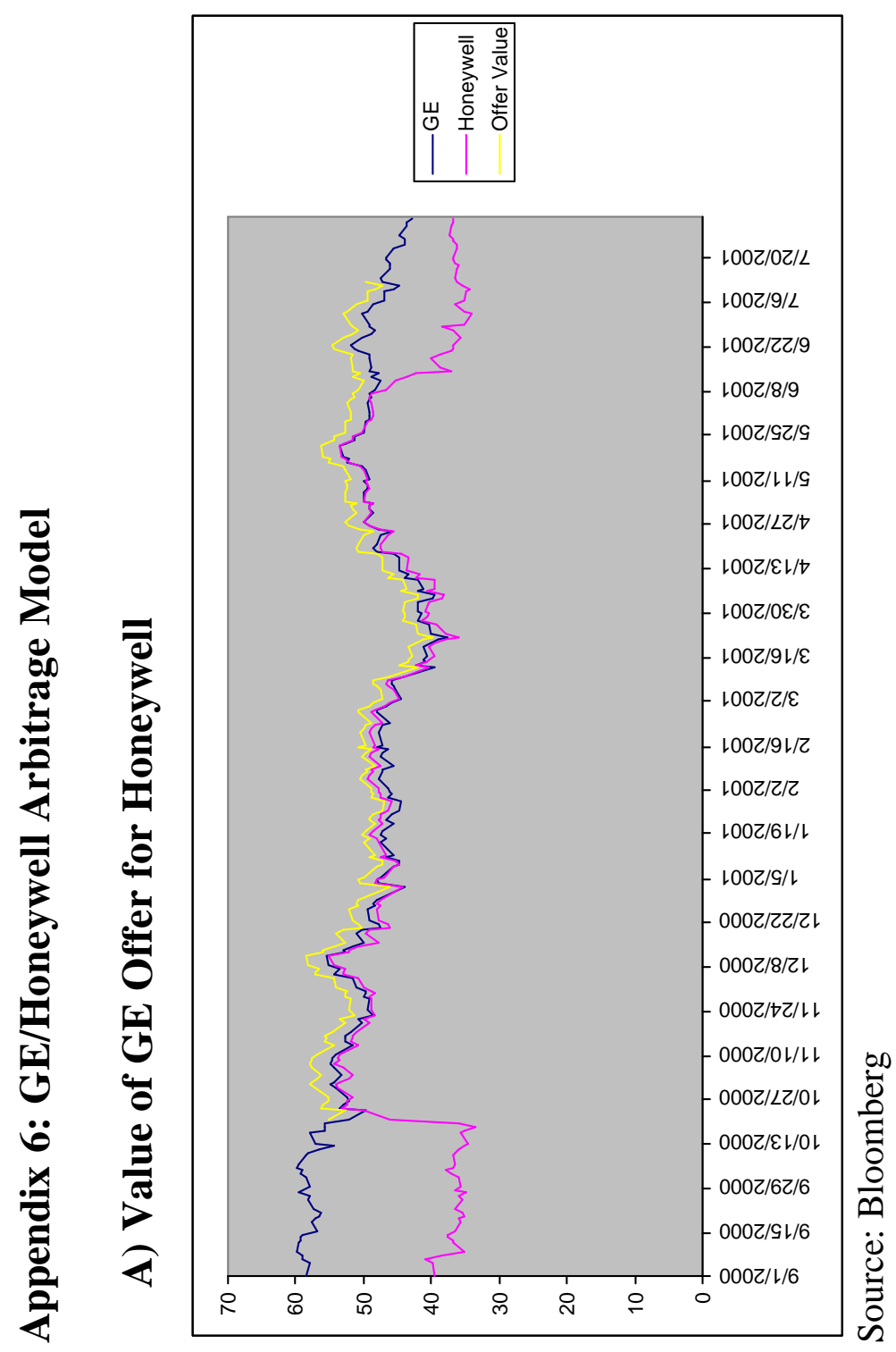



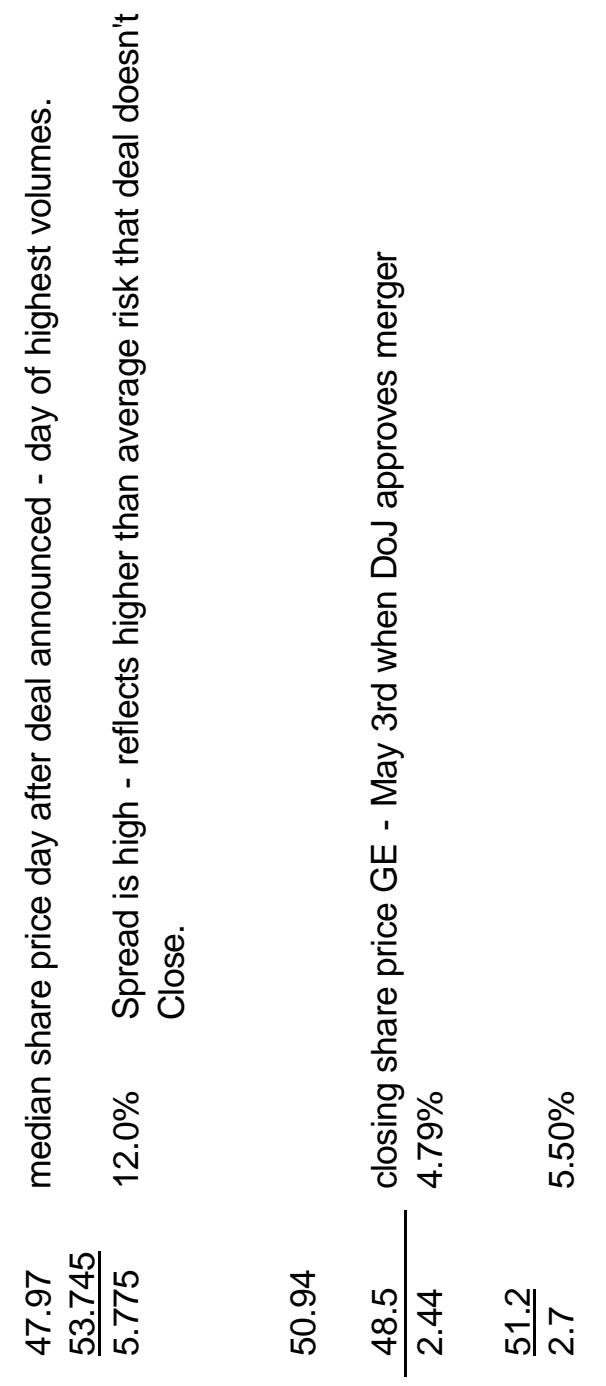

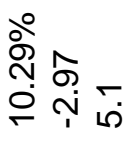
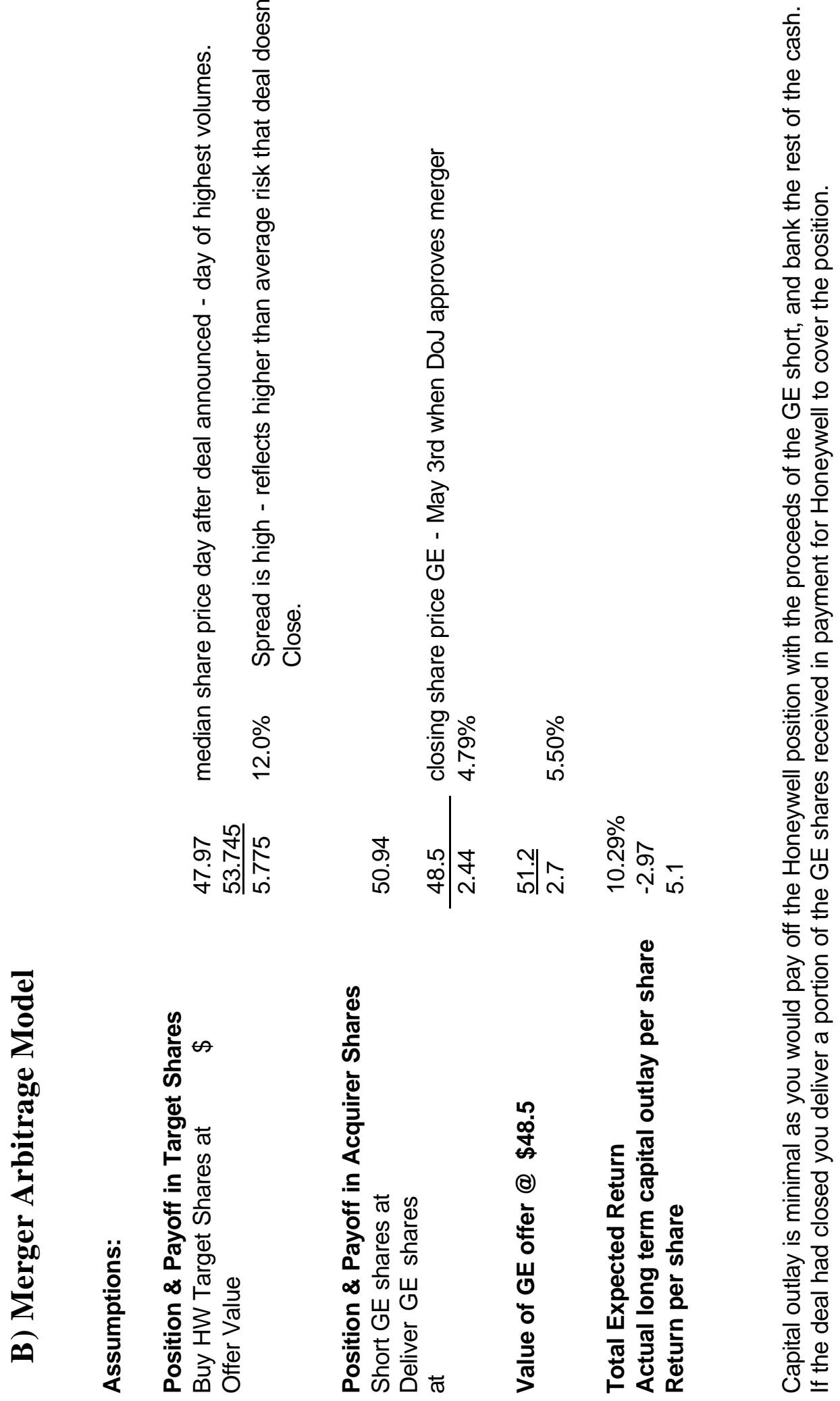


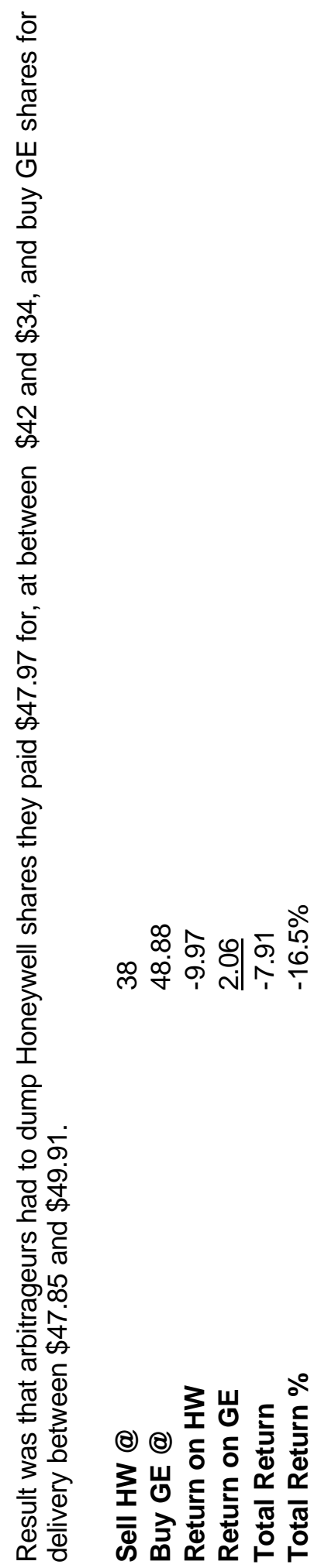




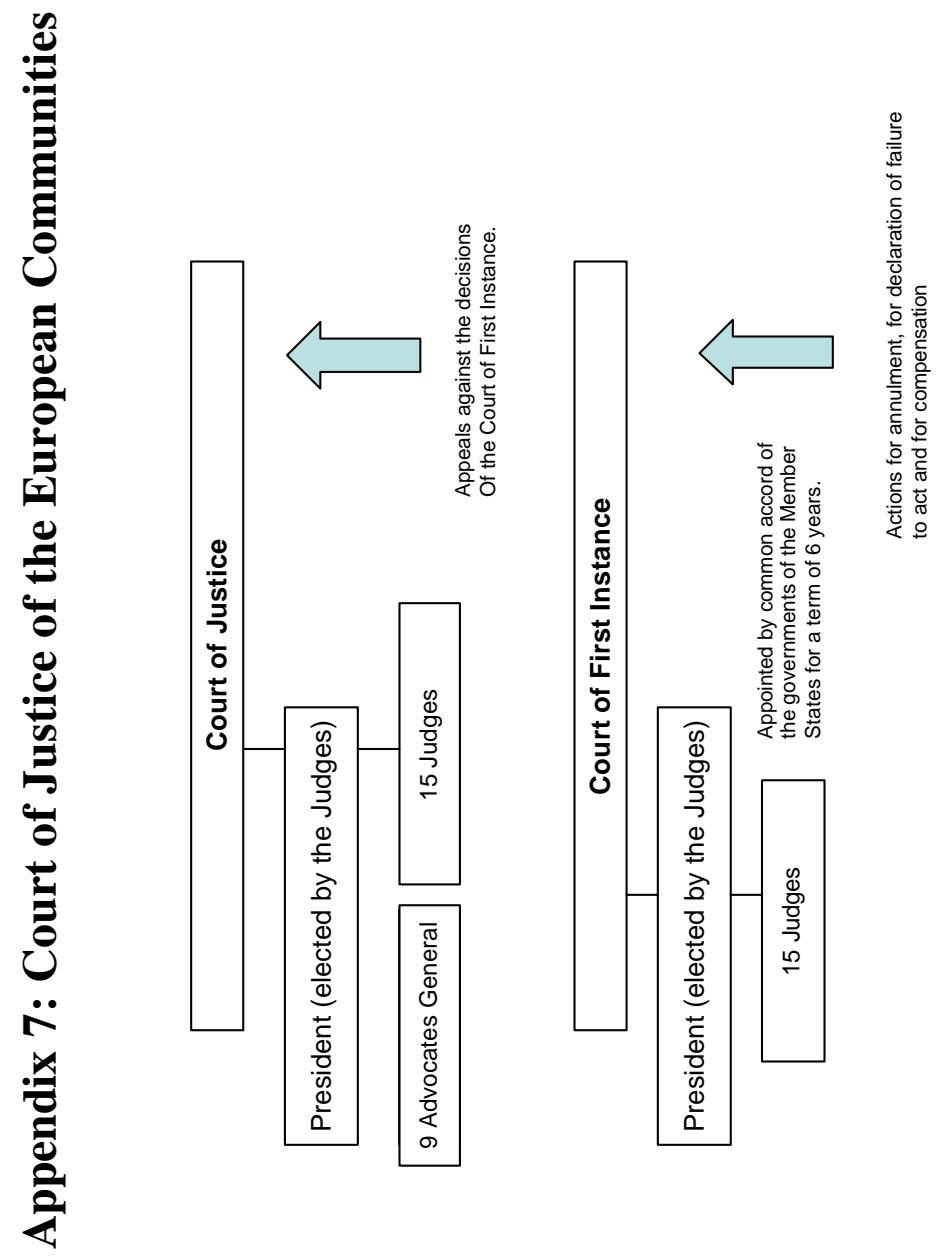

